\title{
Lithofacies and eruptive conditions of the southernmost volcanoes in the world $\left(87^{\circ} \mathrm{S}\right)$
}

\author{
J. L. Smellie ${ }^{1} \cdot$ K. S. Panter ${ }^{2}$
}

Received: 19 March 2021 / Accepted: 21 June 2021 / Published online: 6 July 2021

(c) The Author(s) 2021, corrected publication 2021

\begin{abstract}
Neogene volcanic centres are uncommon in the Transantarctic Mountains but at least three basaltic examples occur within $300 \mathrm{~km}$ of South Pole, above $2200 \mathrm{~m}$ asl and inland of the margin of the West Antarctic Rift System. They are the southernmost volcanoes on Earth and have yielded Early_mid Miocene isotopic ages. Two of the centres, at Mt Early and Sheridan Bluff, have been examined. The centre at Mt Early is unequivocally glaciovolcanic. It formed a tall monogenetic volcanic edifice at least $1 \mathrm{~km}$ high and $>1.5 \mathrm{~km}$ in diameter. It erupted under significantly thicker-than-modern ice, which was probably a fast-moving ice stream at the eruptive site and resulted in a distinctive constructive architecture and lithofacies. It is the first described example of a glaciovolcano erupted beneath an ice stream. The characteristics of the second centre at Sheridan Bluff indicate that it was also a monogenetic volcano but with a shield-like profile, originally c. $6 \mathrm{~km}$ in basal diameter but just c. $400 \mathrm{~m}$ high. It probably erupted in a substantial pluvial lake in an ice-poor or ice-free environment. The strongly contrasting eruptive settings now identified by the volcanic sequences at both centres examined testify to a highly dynamic Antarctic Ice Sheet during the Early—mid Miocene.
\end{abstract}

Keywords Transantarctic Mountains $\cdot$ Surtseyan $\cdot$ Glaciovolcanism $\cdot$ Ice stream $\cdot$ Pluvial lake $\cdot$ Miocene

\section{Introduction}

Volcanic centres that erupted in glacierized settings (i.e. glaciovolcanoes; Edwards et al. 2015; Smellie and Edwards 2016) have the ability to preserve often surprisingly detailed information on the environmental conditions (Smellie 2018). The same is probably true of volcanoes in other, non-glacierized settings, but they have been less well investigated for their environmental record (Duncan et al. 1984). By contrast, refinements to our understanding of glaciovolcanoes, in particular, have enabled numerous critical parameters of past ice sheets to be deduced. The range of parameters is greater than can be deduced

Editorial responsibility: P-S. Ross; Deputy Executive Editor: J. Tadeucci

J. L. Smellie jls55@le.ac.uk

1 School of Geography, Geology and the Environment, University of Leicester, Leicester LE1 7RH, UK

2 School of Earth, Environment and Society, Bowling Green State University, Bowling Green, OH 43403, USA by any other methodology and, uniquely, many are quantifiable (Smellie 2018). However, our understanding of past environmental conditions in Antarctica, which hosts the world's largest and longest-lived ice mass on Earth, has relied almost exclusively on sedimentary and related studies of sequences preserved on Antarctica's continental shelf and obtained during costly drilling programmes (e.g. Barrett and Ricci 2001; Fielding et al. 2011; Levy et al., 2016). Antarctica also hosts the world's largest and longest-lived glaciovolcanic province, spanning $>30 \mathrm{Myr}$ from earliest Oligocene time (LeMasurier and Thomson 1990; Smellie et al. 2021a). In recent years, an increasing but still relatively small number of papers describing Antarctica's glaciovolcanoes has been published, both in a paleoenvironmental context and also to advance our understanding of glaciovolcanism and glaciovolcanic processes generally (e.g. Skilling 1994; Wilch and McIntosh 2000, 2002; Smellie et al. 2008, 2011a,b, 2014, 2018). Many volcanic outcrops remain to be described. They include two small mafic volcanic centres situated within $300 \mathrm{~km}$ of the South Pole, which are the subject of this paper (Figs. 1, 2). They are the most southerly exposed volcanoes on Earth, situated at high elevation and far inland. The volcanoes 
Fig. 1 Map showing the locations of known and inferred Neogene volcanic centres in the southern Transantarctic Mountains (after Licht et al., 2018; Smellie et al., 2021b). The inset shows the location of the field area within Antarctica and the distribution of large volcanic centres in the West Antarctic Rift System (WARS; after LeMasurier and Thomson 1990). WARS boundary after LeMasurier (2008)

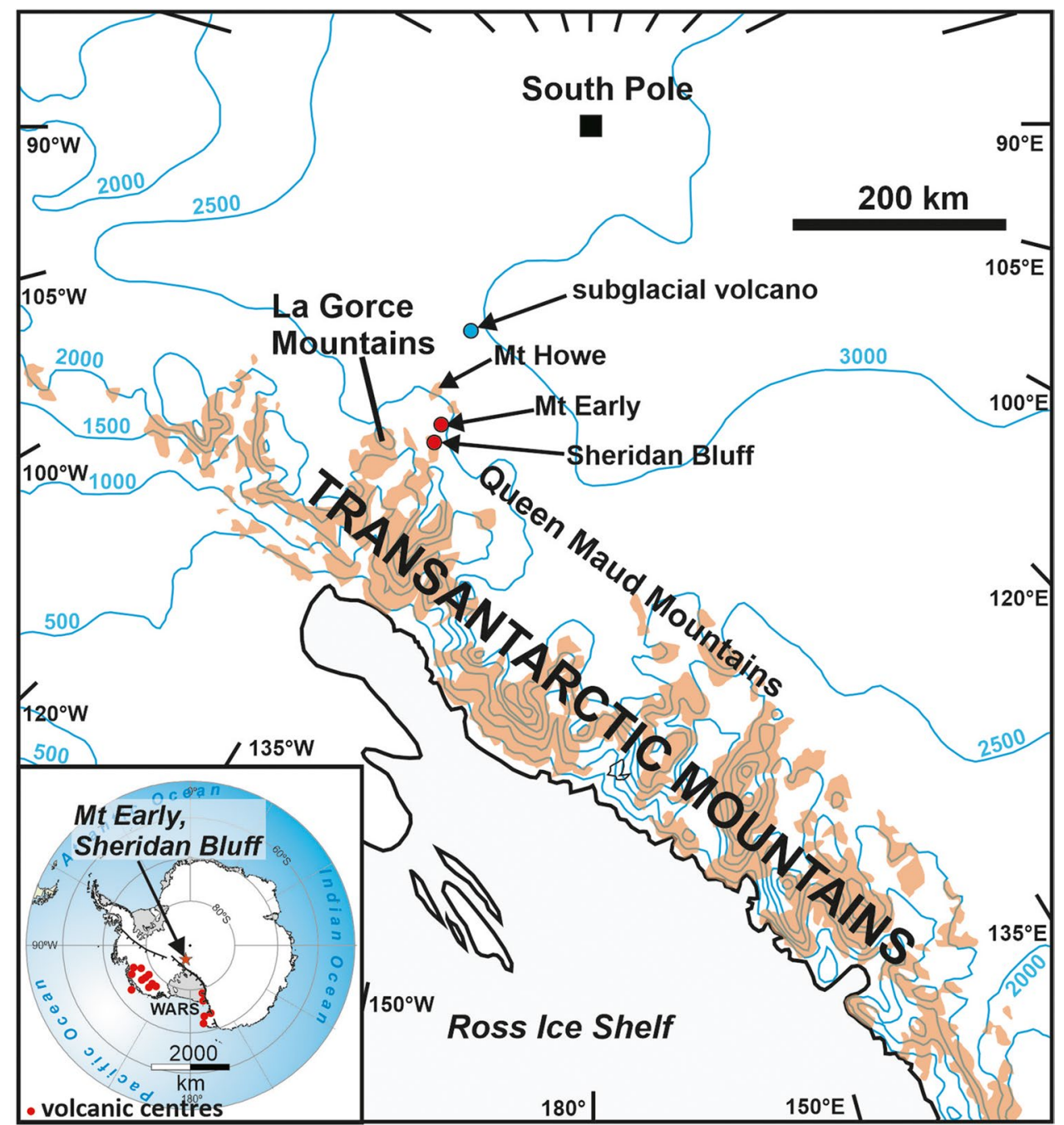

have been described only at reconnaissance level, but they potentially contain unique evidence for eruptive processes and environments in a high polar latitude during the warm Early_mid Miocene.

In this paper, we provide the first detailed descriptions of the lithofacies in two small mafic volcanoes that crop out close to South Pole, together with interpretations of the eruptive environments. A glaciovolcanic setting can be convincingly demonstrated for one of the volcanoes, which was probably erupted beneath an ice stream. It is the first example to be described. The second centre to be examined shows no evidence for glacial conditions coeval with eruption and an ice-poor or perhaps even icefree eruptive environment is indicated. The development of palaeoenvironments in the Transantarctic Mountains during the warm Early Miocene is linked inextricably to the presence of the East Antarctic Ice Sheet (EAIS). They have important consequences for understanding the dynamics of the largest and most stable mass of ice in
Antarctica, and its impact globally on a rapidly warming world (Sugden 1996; Gasson et al. 2016).

\section{Geological setting}

Neogene alkaline volcanic rocks are widespread in Antarctica (LeMasurier and Thomson 1990; Smellie et al., 2021a). Many are glaciovolcanic, i.e. they were erupted in association with an ice cover, and several have been used to provide information on glaciovolcanic eruptive and depositional processes and past glacial environments (e.g. Smellie et al. 1993, 2009, 2011a, 2011b, 2014, 2018; Skilling 1994; Smellie and Hole 1997; Wilch and McIntosh 2000, 2002; Smellie 2001, 2006, 2008; Iverson et al. 2017). Most of the volcanism is associated with the West Antarctic Rift System (WARS), one of the world's largest intra-continental rifts (Fig. 1; e.g. LeMasurier 2008; Siddoway 2008, 
Fig. 2 Map showing the geology of outcrops in the upper Scott Glacier area (after Davis and Blankenship 2005) and published isotopic ages. The locations of moraines containing volcanic clasts are also shown; the clasts are presumed derived from additional volcanic centres, currently unexposed. Note that the ages shown for volcanic rocks at Mt Early and Sheridan Bluff were determined c. 40 years ago and may not be accurate but a general Earlymid Miocene age is indicated for both centres

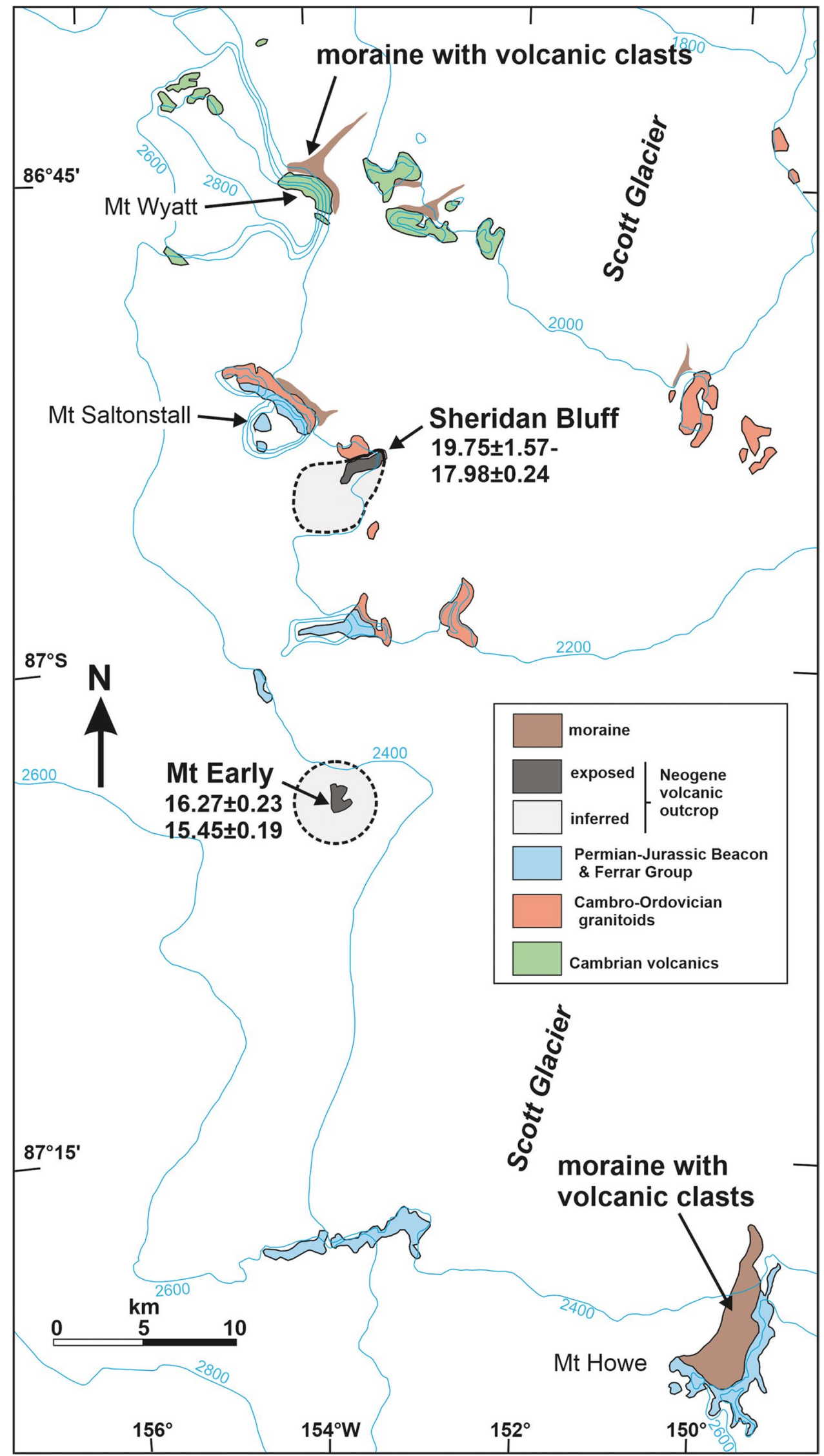


2021; Wilch et al. 2021). Many centres may exist within the WARS but are concealed by the West Antarctic Ice Sheet (e.g. Behrendt et al. 2002; van Wyk de Vries et al. 2018; Licht et al. 2018). They have been identified only by remote-sensing methods and most are unverified (Pedersen et al. 2020; Quartini et al. 2021). The volcanoes cropping out along the southern margin of the rift, in Victoria Land and the Transantarctic Mountains, are assigned to the McMurdo Volcanic Group (Smellie and Rocchi 2021). They consist mainly of large shield and stratovolcanoes with a broad range of basalt to trachyte, rhyolite and phonolite compositions but they also include numerous smaller monogenetic mafic centres with basaltic compositions.

Amongst the most isolated examples are two outcrops in the upper Scott Glacier region of the southern Transantarctic Mountains, at $87^{\circ} \mathrm{S}, 300 \mathrm{~km}$ from South Pole and c. $1000 \mathrm{~km}$ from the nearest exposed representatives of the McMurdo Volcanic Group (Fig. 1). They are the only known Neogene volcanic rocks exposed south of $79^{\circ} \mathrm{S}$ and may or may not be genetically part of the WARS volcanism (Panter et al. 2021). The two Transantarctic Mountains outcrops, together with an additional inferred subglacial volcanic centre nearby, which has been identified beneath the EAIS c. $100 \mathrm{~km}$ closer to South Pole (Fig. 1; Licht et al. 2018), are the southernmost volcanoes in the world (Stump et al. 1980). All three centres are included in the Upper Scott Glacier Volcanic Field (Smellie et al. 2021b). The few published accounts are brief and at a reconnaissance level and the subglacial centre is represented only by volcanic debris found in a moraine at $\mathrm{Mt}$ Howe (Fig. 2) and a subglacial geophysical anomaly (Licht et al. 2018). Although other volcanic centres of similar age may be present nearby, as suggested by abundant volcanic debris in a different moraine (at Mt Wyatt; Fig. 2; information of E. Stump, cited by Smellie et al. 2021b), the locations and characteristics of those putative centres are unknown at present and they are not discussed further in this paper. Preliminary petrological and volcanological results of Mt Early and Sheridan Bluff are given by Panter et al. (2021) and Smellie et al. (2021b). Published isotopic dating indicates that they are Early_mid Miocene in age (Stump et al. 1980; Fig. 2). Both volcanoes have been interpreted as glaciovolcanic and used to provide evidence that the EAIS existed at that time (Stump et al. 1980). Moreover, their presence has also been used to imply significant Cenozoic uplift of the Transantarctic Mountains, to define the lateral extent of the influence of the West Antarctic Rift System (but see Panter et al. 2021), and as support for a tectonic model of lithospheric foundering postulated to explain how the mountain chain became uplifted (Shen et al. 2018; see also Granot and Dyment 2018). Thus, despite their small size, they have been recognised as disproportionately important for a variety of reasons.

\section{Methods}

The study at Mt Early and Sheridan Bluff took place in December 2015 over 5 days. This was sufficient time for making detailed notes, collecting representative samples (for thin sections, isotopic dating and whole-rock analysis) and mapping the limited outcrops. The outcrops were mapped initially onto satellite images but detailed maps depicting the geology in the mainly steep exposed sections were created based on field sketches supported by photographs. Local elevations were estimated using a hand-held Garmin E-Trek GPS with altimeter calibrated daily against a single site (the campsite) for which the elevation was fixed; errors are estimated as c. $\pm 10 \mathrm{~m}$. For the present study, 30 thin sections were examined and 23 rock samples were analysed by XRF and ICP-MS. Details of the analytical methods used and petrological results are presented by Panter et al. (2021). New isotopic dating of the localities is underway and those results shall be presented elsewhere but they are not important for present purposes.

\section{Results of previous volcanic studies}

Prior to our study, very few published geological accounts of the Mt Early and Sheridan Bluff successions existed: i.e. Doumani and Minshew (1965) and Stump et al. (1980, 1990a,b). Compositionally, both outcrops are mafic, varying from alkali and tholeiitic basalt to hawaiite and mugearite (Fig. 3; Stump et al. 1980, 1990a,b; Panter et al. 2021). Mt Early yielded an age of c. $16 \mathrm{Ma}$ by $\mathrm{K}-\mathrm{Ar}(16.27 \pm 0.23$ and $15.45 \pm 0.19 \mathrm{Ma}$; Stump et al. 1980, 1990b). The description by Doumani and Minshew (1965) emphasised that the outcrop was dominated by black, vesicular, columnar olivine basalt associated with numerous ropy contorted bombs, whilst yellowish tuff and tuff breccia occurred mainly in the higher reaches of the nunatak. Conversely, Stump et al. (1980, 1990b) divided the outcrop into a basal shield-shaped pile of black pillow lavas mantled by pillow breccias that grade up into yellow fine-grained 'palagonite breccia'. The latter was described as massive lower down but bedded above. Stump et al. $(1980,1990 b)$ also postulated that there was a capping unit of lava but it was unvisited and they made a broad comparison with subglacial 'moberg' (i.e. tuya) glaciovolcanic centres in Iceland.

Doumani and Minshew (1965) described basalt, vesicular scoria, agglomerate and tuff breccia at Sheridan Bluff, capped by seven to nine pāhoehoe lavas with red scoriaceous surfaces. The lava sequence was described as c. $110 \mathrm{~m}$ thick and said to include ropy contorted bombs. 


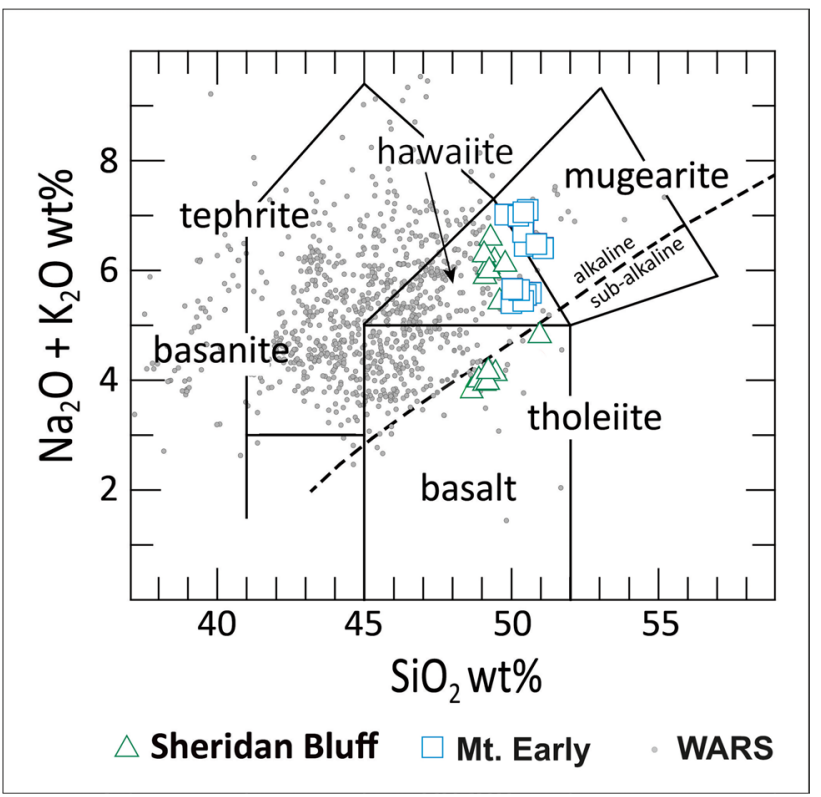

Fig. 3 Total alkalis—-silica diagram (after Le Bas et al. 1986) showing the compositions of lavas in the Upper Scott Glacier Volcanic Field in comparison to mafic compositions $(\mathrm{MgO}>4$ wt.\%) from the West Antarctic Rift System (WARS; Panter 2021 and references therein; other data from Stump et al. (1980) and Panter et al. (2021)). All samples are normalised to $100 \%$ volatile free and the dashed line delimiting alkaline from subalkaline compositions is from Irvine and Baragar (1971)

Stump et al. (1980, 1990a) assessed the entire sequence as c. $200 \mathrm{~m}$ thick, pinching out to the north-west due to a rising, irregular, glacially eroded, striated bedrock surface composed of early Palaeozoic granodiorite. They also described a basal pillow breccia that passed up into hyaloclastite containing broken pillows (up to c. $85 \mathrm{~m}$ thick), followed by nine lavas (110 m thick). The locality was dated as c. $19 \mathrm{Ma}$ in age by ${ }^{40} \mathrm{Ar} /{ }^{39} \mathrm{Ar}$ (range of ages: $19.75 \pm 1.57$ to $17.98 \pm 0.24 \mathrm{Ma}$; Stump et al. 1980 , 1990a). A subglacial origin was inferred mainly from the presence of underlying striated granitoid basement.

\section{Geological descriptions and interpretations of the localities visited}

\section{Mount Early}

Description Mt Early has an exposed diameter of c. 1.0$1.3 \mathrm{~km}$ and rises to c. $2850 \mathrm{~m}$ above sea level (asl). The summit is c. $450 \mathrm{~m}$ above the surrounding ice surface. The conical shape of the nunatak is entirely erosional due to glacial overriding and no primary landform is present. Only the north-east face is well exposed, and the other faces are almost entirely covered by snow and ice. The outcrop can be divided into several lithofacies (Fig. 4; Table 1). The lowest lithofacies form a deposit at least $250 \mathrm{~m}$ thick (base obscured) that extends up to c. $2700 \mathrm{~m}$ asl. It is composed of pillow lava and pillow breccia (Figs. 4, 5) forming a prominent lava mound or shield. Relatively poorly exposed closepacked lava pillows form the core (lithofacies pL; Table 1). The individual lava pillows are encased in thin mantles of dark orange-brown hyaloclastite (Fig. 5a). Moving outward (to the north-east), the unit grades into a massive pillow breccia (lithofacies B/TB) formed of angular pillow lava fragments together with intact (ovoid, flattened and fluidal) lava pillows (Fig. 5b). Lava tubes and irregular sheets with prominent thick glassy chilled margins are also present, and a few conspicuous pockets several metres in extent composed of bright orange lapilli tuff (LT2). The proportion of LT2 increases outward until it dominates but it always contains numerous fragmented lava pillows together with smaller numbers of dispersed flattened and fluidal-looking lava pillows (Fig. 5c). The massive breccia and LT2 form a carapace that drapes the pillow lava core, thinning updip; massive pillow breccia continues to higher elevations, underneath 'The Nubbin' (Fig. 4). A broad sense of an east-northeast dip (i.e. out of the nunatak on the north-east face) is consistently suggested by shallow dips on the lava tubes and many of the flattened and fluidal lava pillows. The orange, massive LT2 is overlain by initially massive then stratified orange and grey fine lapilli tuffs (LT1; Table 1). The transition between LT2 and LT1 is gradational and occurs over a few tens of metres of section characterised by a rapid increase in the proportion of vesicular juvenile lapilli.

The basal pillow lava and pillow breccia lithofacies are overlain by type 1 lapilli tuff, which varies from mainly orange to less commonly grey in colour. Planar discontinuous stratification is locally present and is slightly wavy on a scale of a few $\mathrm{cm}$. The stratified deposits can be classified as diffusely stratified fine lapilli tuffs (Fig. 5d, e; Branney and Kokelaar 2002; White and Houghton 2006). Outsize blocks of broken lava pillows up to c. $35 \mathrm{~cm}$ in diameter occur, but are generally uncommon. Impact structures, ash-coated lapilli (sensu Brown et al. 2012) and dune bedforms were not observed. The grey form of LT1 occurs in large (up to a few tens of metres across) block-like masses with variable orientations within orange LT1 in the uppermost sections of the nunatak (above c. 2700 m; Fig. 4a). The outcrops of grey LT1 are usually crossed by a network of shears, many of which are also present in the underlying LT2 and pillow breccia lithofacies (Fig. 6a-c). Although contacts between the two colour variants of LT1 are abrupt in places, other contacts seem gradational over a few $\mathrm{cm}$.

Massive, grey, fine, texturally polymict lapilli tuff (pLT) is distinguished by the presence of distinctive red lapilli. 
Fig. 4 (a) View of Mt Early with the geology indicated (after Smellie et al. 2021b, modified). Spot elevations determined by hand-held GPS with altimeter calibration are also shown. 'The Nubbin' is an informal name. The line of section depicted in (b) is also indicated (labelled A-D). (b) Schematic cross section of the north-east flank of Mt Early to show the distribution of the major lithofacies. The boundaries between each are gradational. Although deposits of three discrete collapse events are suggested, several collapses may have contributed to each

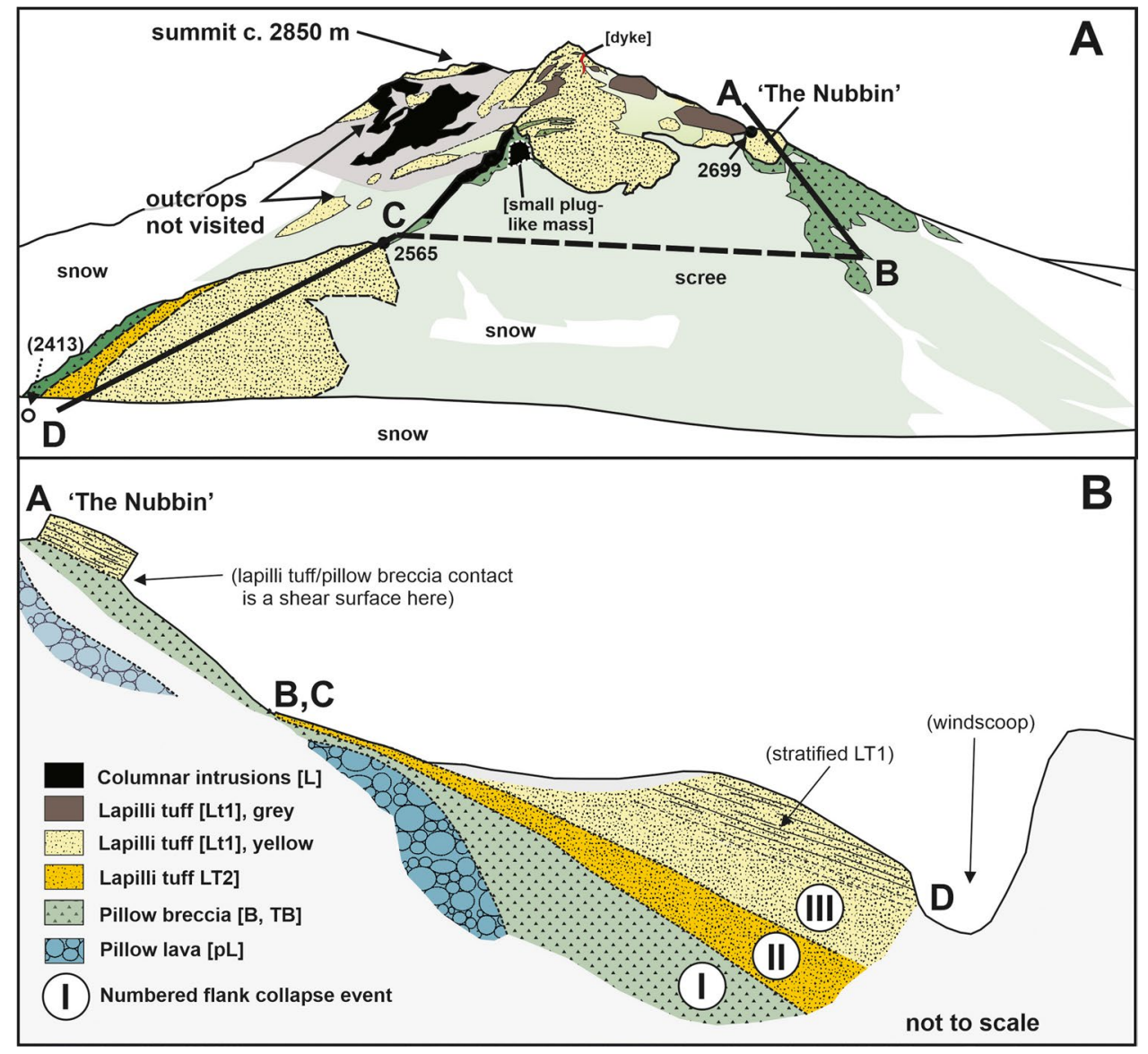

Similar lapilli are absent in the other lapilli tuff lithofacies although pLT is probably compositionally monomict like those lithofacies (Table 1). It is a minor lithofacies seen only on the north-west ridge at c. $2750 \mathrm{~m}$. It consists of a narrow linear outcrop a few metres in width and with unclear margins that trends c. 10-20 $\mathrm{m}$ up the ridge.

Intrusive columnar-jointed grey lava (iL; Table 1) forms conspicuous irregularly shaped outcrops on the high, largely inaccessible north-east face below the summit of Mt Early and on its north-east ridge (above $\mathrm{C}$ in Fig. 4a). In addition, small neck-like masses a few metres in diameter are present and are in contact with coarse grey lapillistone (LP; Fig. 5f). The grey lapillistone varies to dark grey agglutinate composed of large vesicular bombs. Other intrusions are minor and comprise rare dykes. A bifurcated example with pillow-like bulbous margins occurs low on the north-east flank. A prominent grey-green columnar dyke also occurs on the summit ridge (also noted by Stump et al. 1980, 1990b) but was not visited by us. Both dykes intrude orange LT1 deposits.

Effects of deformation are common and conspicuous at Mt Early (Figs. 6, 7). In addition to numerous small-displacement (c. $5 \mathrm{~cm}$ ) minor faults seen offsetting stratification in LT1 deposits, the deformation is mainly characterised by pervasive networks of criss-crossing pale grey shears and prominent, steep-dipping shear surfaces that can sometimes be traced for tens of metres (Fig. 6a-c). The shears affect the basal breccia (B, TB) and both LT1 and LT2. They occur as pale khaki planar bands a few cm thick, rarely up to $35 \mathrm{~cm}$ (Fig. 6d), composed of fine tuff or lapilli tuff rich in fine tuff matrix, and are dominated by finely fragmented sideromelane. Some shears show multiple striated surfaces (Fig. 6b). Also present are locally numerous bands of laminated fine to coarse tuff a few centimetres to $1 \mathrm{dm}$ wide and a few dm in lateral extent that are curviplanar and often crosscut one another. On a much larger scale, the sharp planar surfaces that separate large masses of orange LT1 and khaki grey LT1 deposits have a wide range of generally steep-dipping attitudes and are presumably faults. Deformed (folded) and broken bedding on a smaller scale (few metres) is also present but rare (Fig. 6e, f). Grey LT1 and fine pillow breccia are also present back-injected as thin sometimes sinuous dyke-like sheets in LT1 and LT2 deposits and are sometimes traceable directly into underlying breccia (Fig. 7a). Finally, some exposures show a wavy contact between massive pillow breccia and orange LT1, with numerous offshoots of pillow breccia injecting the lapilli tuff and occurring as diffuse masses of pillow breccia mingled with lapilli tuff (Fig. 7b). 


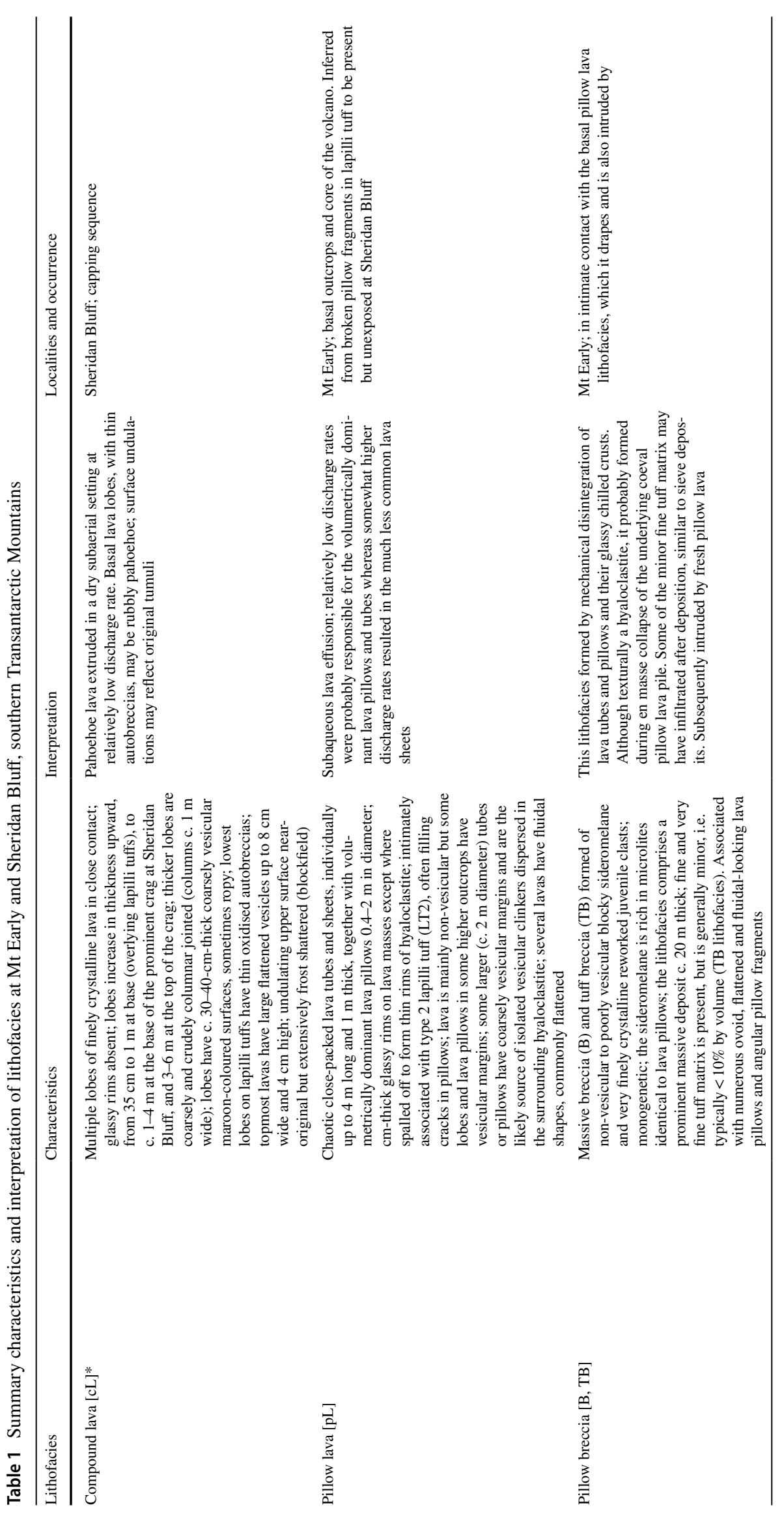




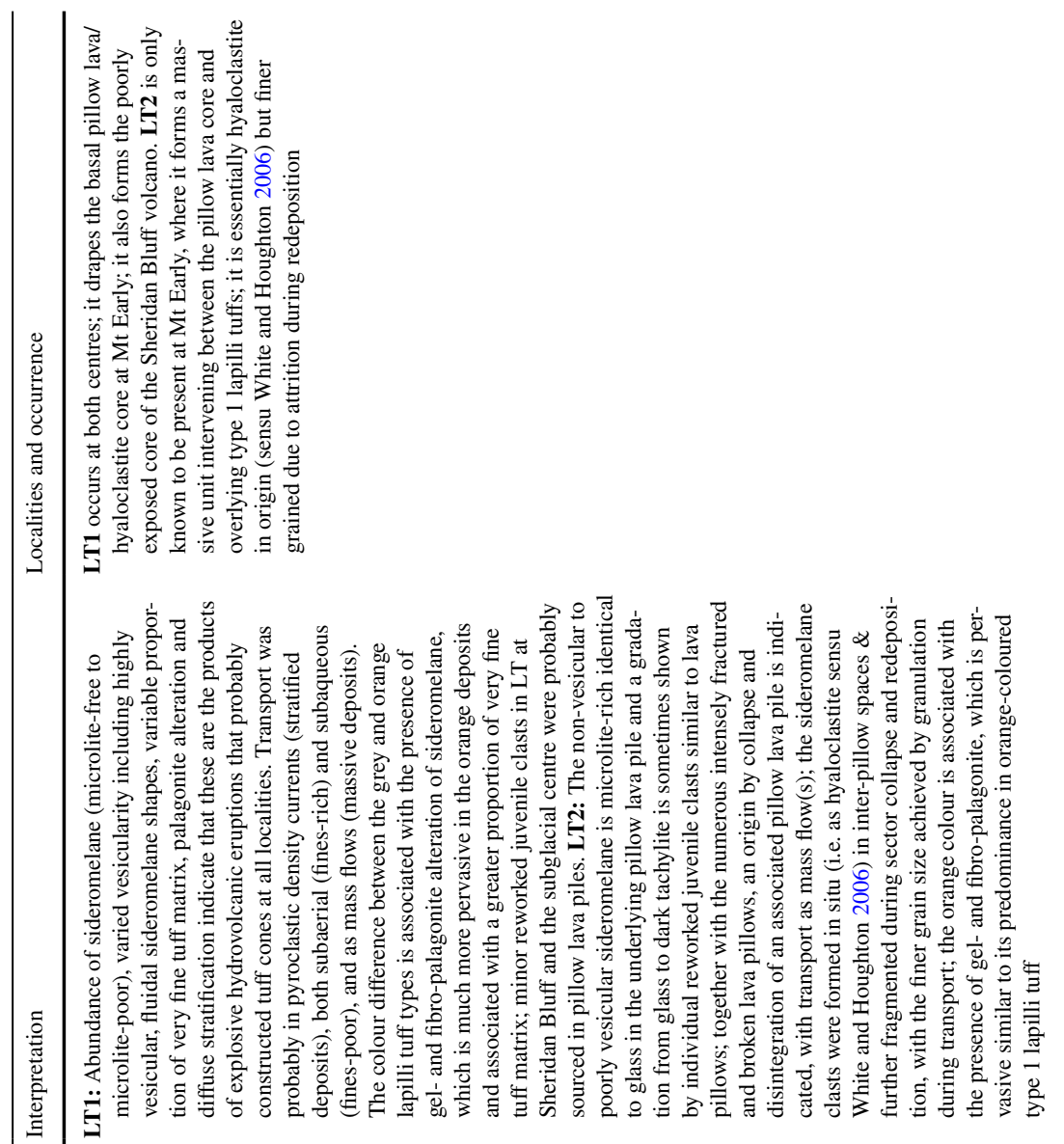

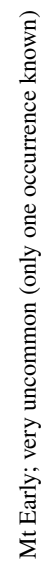

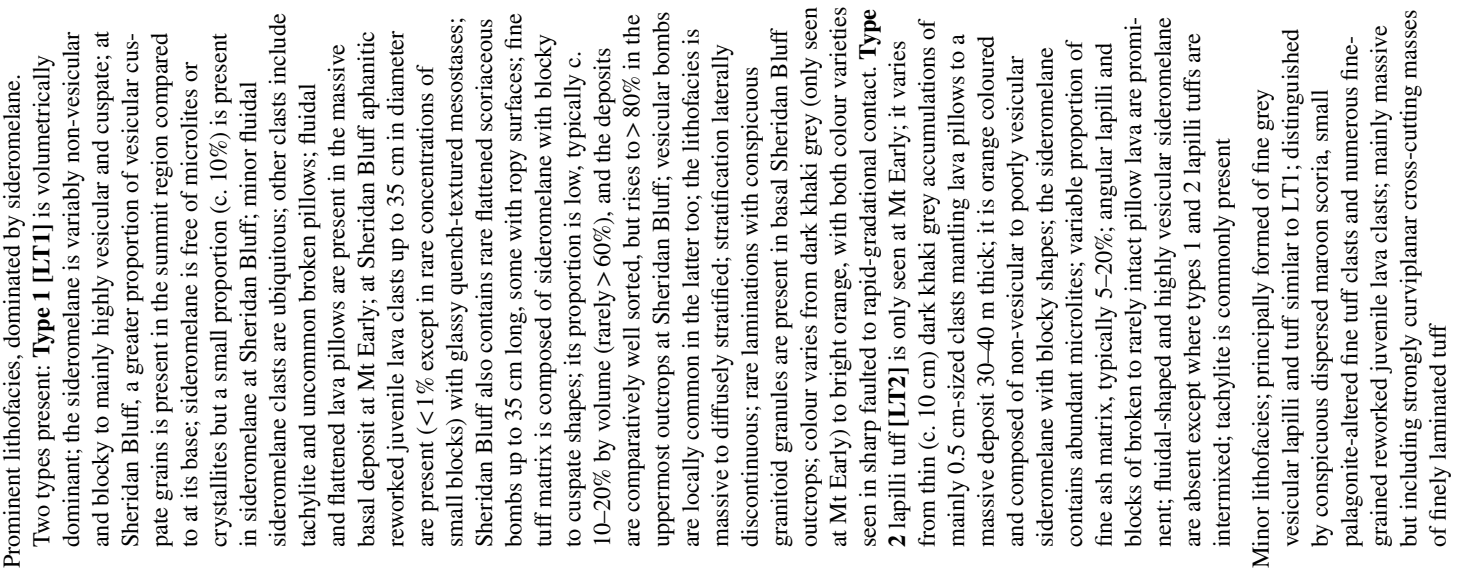




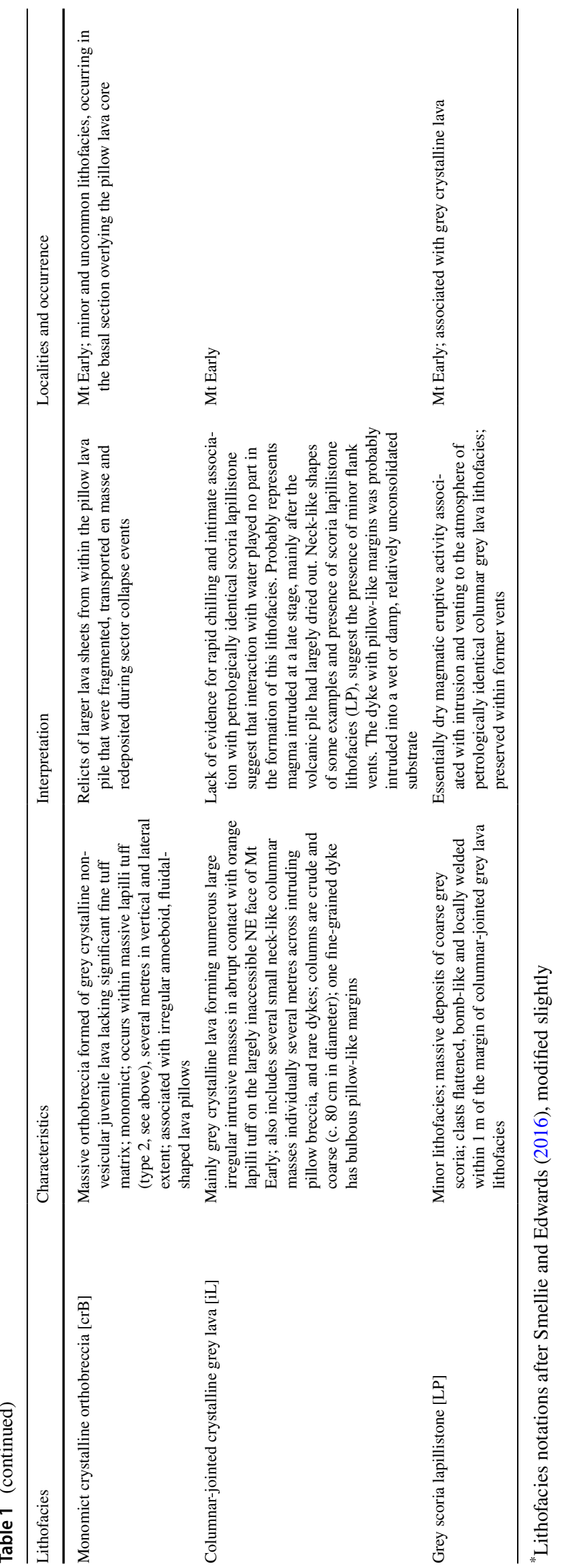

Interpretation Despite the abundant structural discordances, there is no evidence for internal erosional surfaces at $\mathrm{Mt}$ Early that might indicate significant time breaks during the eruptive period, the geochemical composition is homogeneous (Fig. 3), and we suggest that the volcano was monogenetic. The sequence architecture indicates a large basal pillow lava-pillow breccia-lapilli tuff (LT2) mound draped by a relatively thin carapace of explosively formed lapilli tuffs (LT1) probably < c. $100 \mathrm{~m}$ thick in the summit region, tens of metres thick on the lower flanks. The mound formed entirely under water by lava effusion, related hyaloclastite formation, and some collapse events discussed below.

Deposits of LT1 are hydrovolcanic, formed during explosive eruptions. This is supported by the presence of abundant, often palagonite-altered, angular sideromelane fragments with variable vesicularity, including some fluidal shapes, which indicate rapid cooling (Zimanowski and Büttner 2003). Also, the wavy, discontinuous, diffuse fine stratification is comparable with that shown by pyroclastic density currents (Branney and Kokelaar 2002). Basement clasts are absent, whereas fragments derived from lava pillows are present, though uncommon. This implies that the explosivity that generated the lapilli tuffs took place mostly above the pillow lava/breccia mound, at a high level in a water-saturated vent. The hydrovolcanic interaction was with surface water within a saturated volcanic edifice rather than with groundwater, which typically generates abundant country-rock clasts (Sohn 1996; White 1996). Moreover, most of the LT1 outcrops occur at lower elevations than the top of the pillow lava pile so transport and deposition were also predominantly or solely subaqueous. Thus, following an early effusive pillow mound stage, explosive hydrovolcanic eruptions created a pyroclastic pile. The presence of a large pillow lava pile, indicative of eruption associated with surface water, and the lithofacies architecture of the edifice resemble that of Surtseyan volcanoes formed subglacially, in the sea or in pluvial lakes (e.g. Jones 1969; Staudigel and Schmincke 1984; Smellie 2001; Schopka et al. 2006; Edwards et al. 2009; Skilling 2009). However, the inland location of Mt Early and its high elevation (base above $2500 \mathrm{~m}$ asl) indicate that it cannot have erupted in the sea. Moreover, Mt Early is surrounded on three sides by the broad upper reaches of Scott Glacier, which merges gradually southwards with the polar plateau. The current surroundings are an almost featureless snow and ice plain, which extends for $2000-3000 \mathrm{~km}$ before descending to the Southern Ocean. On the north side, the Transantarctic Mountains cascade down into the Ross Embayment. Additionally, the summit of the pillow pile (representing subaqueous effusion) is at c. $2700 \mathrm{~m}$ asl, i.e. well above the surrounding modern ice plain. Taken together, there is no feasible evidence for a palaeotopography that could have 
Fig. 5 Compendium of lithofacies characteristic of Mt Early. (a) Nested close-packed lava pillows (lithofacies $\mathrm{pL}$ ) with thin orange-coloured mantles of hyaloclastite; the individual pillows are c. $1 \mathrm{~m}$ in diameter but vary to c. $2.5 \mathrm{~m}$ (out of view). (b) Close view of pillow breccia formed of angular breccia (lithofacies B); note angular clast shapes and outsize broken lava pillow block; the lens cap is $6 \mathrm{~cm}$ in diameter. (c) Type 2 lapilli tuff (orange-brown coloured) composed of fine hyaloclastite, within which are numerous dispersed large lava pillows; the pillows are often flattened and have fluidal shapes (example outlined at lower right); the ice axe (ringed) is c. $70 \mathrm{~cm}$ long. (d) and (e) View and close up of diffusely stratified type 1 lapilli tuff; the notebook is $16 \mathrm{~cm}$ long. (f) Small plug-like mass of intrusive grey columnar-jointed lava (lithofacies iL) showing no evidence of rapid chilling; note outcrop of coeval dark grey scoria lapillistone with numerous large flattened bombs (lithofacies LP) to left of the ice axe
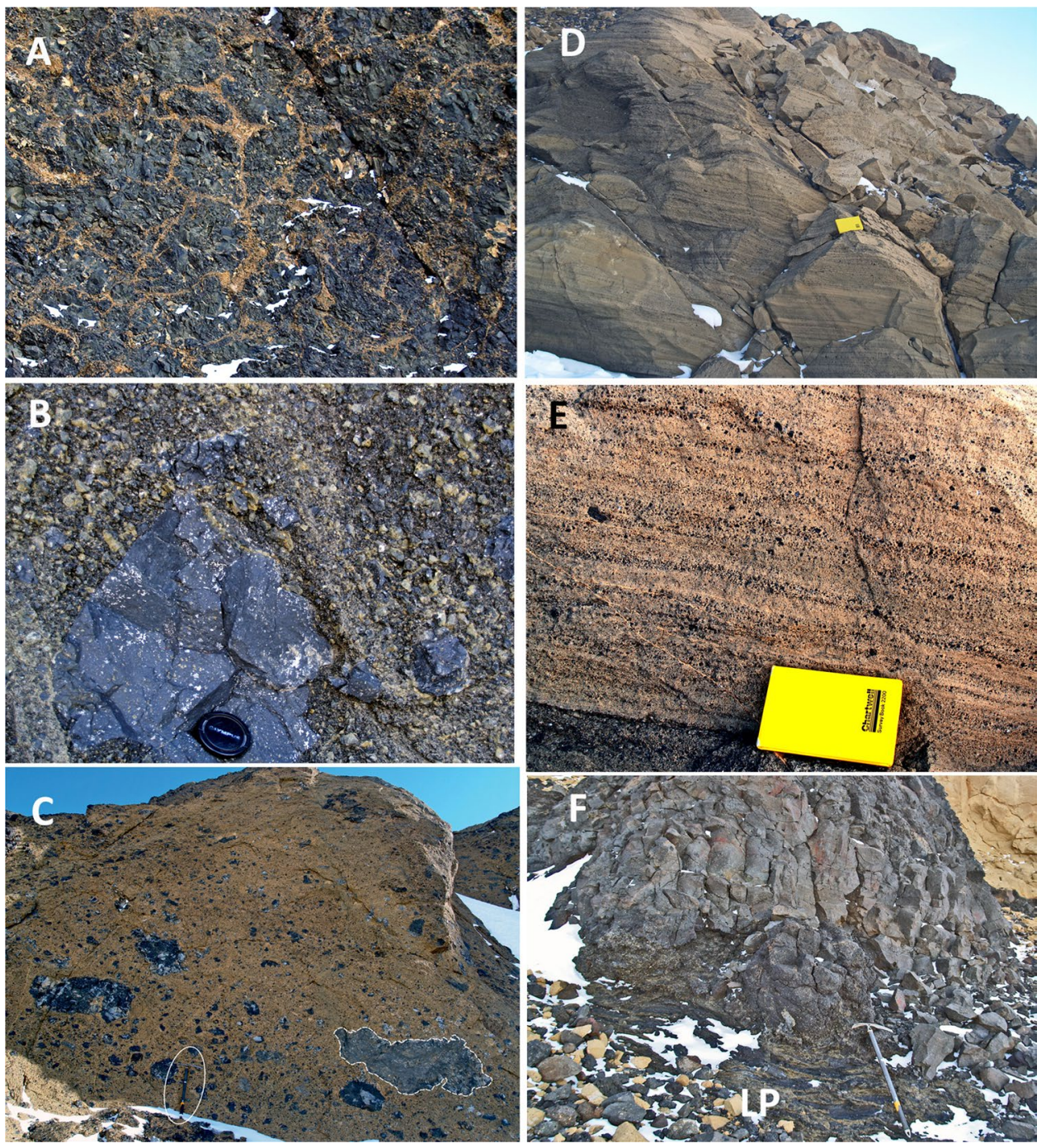

ponded a pluvial lake. Therefore, an interpretation as products of an eruption under a coeval ice sheet is inescapable, as postulated by Stump et al. (1980, 1990b).

Fines-poor pillow breccia forms a massive deposit draping the pillow lava core of the volcano. It grades out rapidly into bright orange LT2, texturally similar to pillow breccia but finer, and the two units become thinner up-dip and may wedge out (Fig. 4b). A genetic link to the underlying pillow lava mound is provided by the abundance of microlite-rich sideromelane in both clastic lithofacies (B/TB, LT2), which is also a feature of glassy rinds to the lava pillows but not sideromelane in LT1. Monomict, finely crystalline clasts are also abundant. Despite the different predominant grain sizes, the pillow breccia and LT2 lithofacies were sourced in the pillow lava pile and were derived from disintegrated lava pillows. However, their massive nature suggests that they were emplaced en masse, probably during discrete collapse events. The gradational contact suggests that the pillow breccia was still unconsolidated at the time and mixed with LT2.
LT2 is essentially a more finely granulated version of the breccia. The differing mean grain sizes between the breccia and LT2 is inferred to be caused by additional attrition and disintegration of larger clasts in the latter, possibly caused by a (pillow lava) source location inferred to be much higher up in the volcanic pile. LT2 also contains admixed vesicular hyaloclasts similar to those in the type 1 lapilli tuff, implying that at least some explosive hydrovolcanic eruptions were also occurring coeval with deposition of LT2. Instability caused by seismicity associated with the explosivity may have been at least partly the cause of the collapse event(s) that gave rise to LT2.

The basal LT1 deposits are also massive, which is unusual for both subaqueous and subaerial tuff cones or tuff rings, which are characteristically well stratified (e.g. Sohn 1996; Cole et al. 2001; Brand and Clarke 2009; Sohn et al. 2012; Brand and Broz 2015; Broz and Németh 2015). We suggest that they were deposited as mass flow(s), similar to the underlying pillow breccia and LT2 deposits. All three 


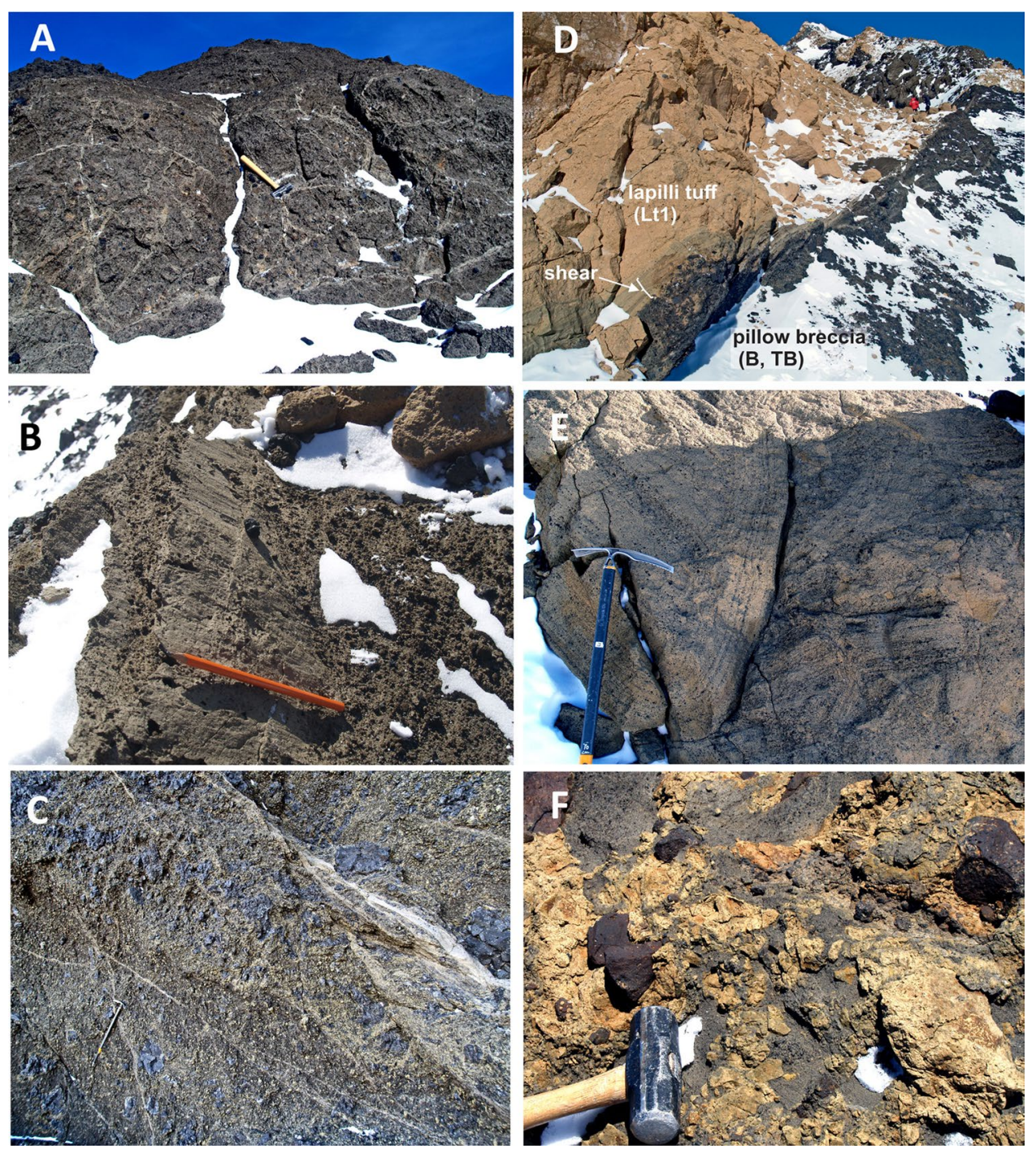

Fig. 6 Compendium of deformational features within different lithofacies at Mt Early. (a) Grey type 1 lapilli tuffs crossed by an anastomosing network of pale-coloured shear planes; the hammer is $35 \mathrm{~cm}$ long. (b) Close view of a shear zone separating pillow breccia (below) and grey lapilli tuff (LT1; above); prominent striations are present on multiple sub-surfaces within the shear; the pencil is $14 \mathrm{~cm}$ long. (c) Numerous pale-coloured cross-cutting shear planes within massive pillow breccia; the ice axe is c. $70 \mathrm{~cm}$ long. (d) Sheared contact between massive pillow breccia (dark grey) and orange diffusely stratified type 1 lapilli tuffs at the base of The Nubbin; the fawn-grey

clastic lithofacies (i.e. B/TB, LT2, LT1) also contain broken and intact lava pillows, some with flattened, fluidal and irregular shapes, attesting to coeval pillow effusion and intrusion. Many of the lava pillows were deformed while still molten during collapse(s) of the pillow pile, but others were probably intruded. Additionally, the observed upward gradation from massive LT1 into diffusely stratified LT1 confirms that the collapse(s) affecting LT1 deposits took place during the construction of the Mt Early volcano and are not due to much younger, unrelated post-eruption collapse events. It shear surface separating the two lithofacies is c. $30-35 \mathrm{~cm}$ wide and composed of thin, sub-parallel, wavy bands of pale greenish-grey milled lapilli tuff; person in red anorak at top right gives scale. (e) Folded and broken beds of diffusely stratified type 1 lapilli tuffs. (f) Broken and mixed fragments of orange type 1 lapilli tuffs in homogenised grey type 1 lapilli tuff matrix; several angular accessory clasts (likely pillow fragments) are also present (darkest grey); the orange lapilli tuffs must have been at least partly lithified prior to disintegration; the hammer head is c. $13 \mathrm{~cm}$ in length

is likely that early-formed massive lapilli tuffs (LT1) were transported initially as pyroclastic density currents and formed bedded deposits (cf. Branney and Kokelaar 2002) prior to the inferred flank collapse and loss of stratification.

In a glacial setting, flank instability is promoted by the removal of support caused by melting back of the surrounding buttressing ice. Similar instabilities also occur in some Surtseyan tuff cone edifices constructed in a marine setting (e.g. Wright et al. 2008; Watts et al. 2012) but they are believed to be particularly characteristic of many 


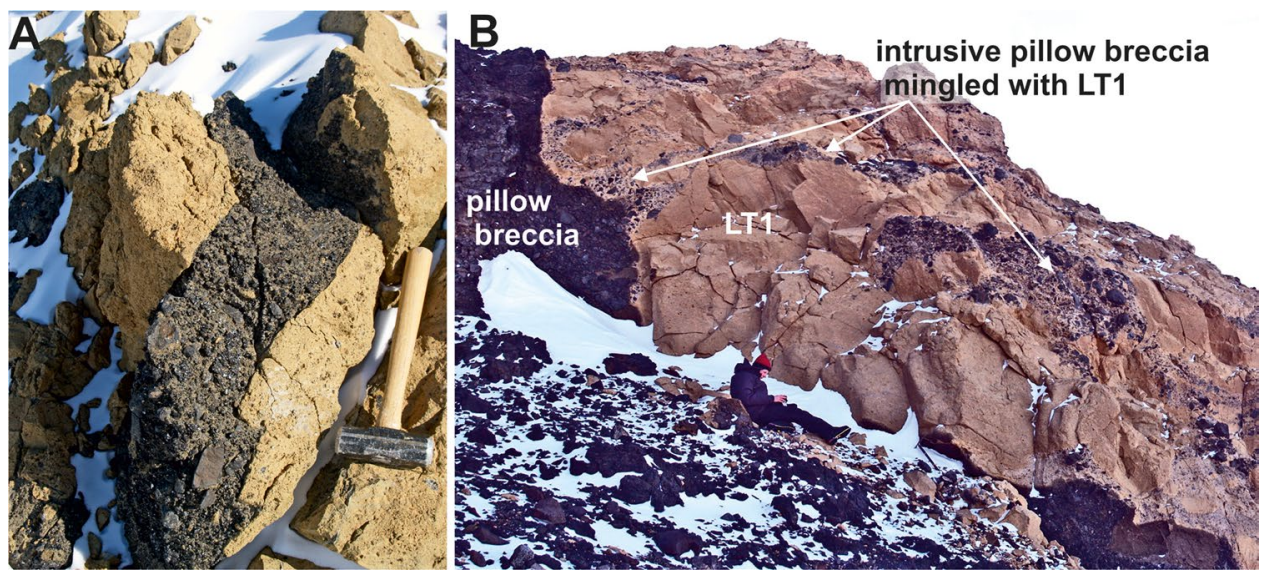

Fig. 7 (a) Thin dyke of dark grey pillow breccia (hyaloclastite) intruding a fracture in orange type 1 lapilli tuff; the sharp margins of the dyke suggest injection into a relatively consolidated host. The hammer is $30 \mathrm{~cm}$ long. (b) View showing dark grey massive pillow breccia abutting orange type 1 lapilli tuffs (LT1); the contact between

glaciovolcanic centres, and are often associated with prominent slump scar structures (Smellie 2018). Conspicuous evidence for fracturing, shearing and faulting is present in all the clastic deposits at Mt Early, and large broken masses of grey LT1 are juxtaposed with orange LT1. Thin dykes and stringers of hyaloclastite locally intrude LT1 and were probably sourced in pillow breccia (Fig. 7), indicating that both the breccia and LT1 lithofacies were unconsolidated at the time. Intrusion of the hyaloclastite was probably due to local fluidisation caused by tremors associated with settling and collapses of the volcanic pile. The finely curviplanar laminated fine to coarse tuff bands are small clastic dykes that were probably back-injected into the lapilli tuffs during multiple episodes of transient high hydraulic pressures induced during disturbance. However, Ross and White (2005) also described very similar clastic dykes formed of laminated fine to coarse tuff intruding coarser (lapilli tuff and tuff breccia) diatreme deposits, which they ascribed to scavenging of fines from the unlithified coarser host caused by fluidization driven by the magmatic heat of coeval intrusions. The abundant features of deformation indicate that edifice instability was significant and continued repeatedly throughout the eruptive period. The presence of lava pillows, some with fluidal shapes and probably intrusive, and the dyke-like masses of pillow breccia indicate that the eruption continued after the flank collapses occurred, and that the volcanic pile was also wet and unconsolidated at the time.

The widespread pervasive nature of the deformation observed, mainly as multiple anastomosing shears together with the evidence for more than one substantial collapse deposit (i.e. massive deposits of pillow breccia, LT1 and LT2; Fig. 4b), is unusual and has not previously been documented in other glaciovolcanic edifices, implying that the two lithofacies is wavy and shows offshoots of pillow breccia mingled with lapilli tuff that intrude the lapilli tuff, together with numerous isolated diffuse 'swarms' of pillow breccia clasts mingled with lapilli tuff; the relationships suggest that the two lithofacies were unconsolidated at the time of injection

uncommon circumstances were responsible. The field relations suggest that the instability occurred when the lithofacies were variably consolidated and unconsolidated (Fig. 7). The evidence for lava pillow injection continuing during and after deposition of multiple flank collapse deposits suggests that the volcano was repeatedly destabilised and deformed prior to deposition of the final drape of stratified LT1.

LT1 deposits crop out right to the summit of Mt Early, i.e. at c. $2850 \mathrm{~m}$ asl. Although the summit itself was not reached, the lower outcrops are mainly poor in fine tuff matrix and comparatively well sorted, with empty pore spaces. Neither are common characteristics of subaerial lapilli tuffs formed from pyroclastic density currents, which are generally rich in fine tuff (also seen at Sheridan Bluff, see below). We infer that the fines-poor characteristic is a result of water transport and deposition. Products of shallow-water explosive eruptions (water depths of a few tens of metres) can be variably fine ash rich depending on the final transporting medium (in air or water; e.g. Cas et al. 1989; Belousov and Belousova 2001; Brand and Clarke 2009). Very fine ash transported in sediment gravity currents is known to commonly bypass the volcanic edifice in subaqueous and subglacial tuff cones, perhaps by stripping of the low-particle concentration zone of fine ash on top of stratified flows; gravitational settling creating a better-sorted 'undercurrent' relatively poor in fine ash; and turbulence keeping the fine-grained sediment load in suspension and transporting it to distal areas (cf. Smith 1986; White 1996, 2000; Belousov and Belousova 2001; Smellie 2001). Subaqueous pyroclastic density current deposits sourced in collapsed, very wet Surtseyan jets (e.g. the 'water-rich pyroclastic base surges' of Belousov and Belousova 2001) are also typically fines poor, unlike their subaerial counterparts. We therefore infer that a variety 
of fines-stripping processes are probably more efficient in subaqueous compared with subaerial settings.

The absence of accretionary lapilli and ash pellets, which are a common feature of explosively generated hydrovolcanic deposits, might also be environmentally significant. Brown et al. (2010) showed that ash pellets characteristically nucleate in eruption plumes, whereas accretionary lapilli form when the pellets fall into and are transported within subaerial pyroclastic density currents. If the tephras at Mt Early were transported and deposited subaqueously, any ash aggregates falling into water would disintegrate and would be unable to form accretionary lapilli (Moore and Peck 1962; Russell et al. 2013). Alternatively, the conditions in the eruption might simply have been insufficient to create accretionary lapilli or ash pellets. LT1 outcrops situated below the top of the coeval pillow mound were selfevidently water-emplaced and we suggest that deposition of most or all of the LT1 lithofacies at Mt Early was also probably subaqueous. The absence of impact structures beneath admittedly uncommon lava blocks is also consistent with this interpretation, since sags require ballistic transport and high-impact velocities, which are more likely in a gas rather than water setting (White 2000).

\section{Sheridan Bluff}

Description The geological sequence at Sheridan Bluff is simple and comprises just three parts, from base up: (1) granitoid forming the local basement; (2) lapilli tuffs; and (3) lavas (Stump et al. 1980, 1990a; Fig. 8). Only the capping lavas are well exposed, mainly in a 50-m-high cliff at the eastern limit of the outcrop (Sheridan Bluff, s.s.; Fig. 8b). The underlying granitoid is exposed in three places directly beneath volcanic rocks (Fig. 8b). A large CambroOrdovician granitoid outcrop is present on the north-west side, at Mt Saltonstall, together with Beacon Supergroup sedimentary strata (Permian; Davis and Blankenship 2005); a much smaller granitoid outcrop is also present at an unnamed bluff to the south (Fig. 2). Below Sheridan Bluff, the granitoid forms several small glacially rounded, polished and locally striated roches moutonées, two of which are overlain by orange laminated tuff and lapilli tuff. The striations are orientated perpendicular to the rock face and trend under the lapilli tuffs. The disposition of the basement outcrops surrounding the volcanic outcrops at Sheridan Bluff indicates that the latter accumulated in a topographical hollow.

The basal $80 \mathrm{~m}$ of the volcanic sequence, as exposed on the north side, is much obscured by lava scree but scattered exposures indicate that they consist of khaki-yellow, massive fine lapilli tuff (LT1; Figs. 8b, 9a; Table 1). Sideromelane in these lower deposits is mainly blocky and poorly vesicular but highly vesicular cuspate lapilli are also present. Close to the contact with overlying lavas, the lapilli tuffs contain numerous (25\%) maroon-coloured scoria up to $20 \mathrm{~cm}$ across (mainly $<3 \mathrm{~cm}$ ) and a 4-cm-thick bed of faintly ruddy-coloured well-sorted fine tuff. A few lower exposures show indistinct discontinuous planar stratification and there is a fine lapilli tuff bed with numerous angular blocks of finely crystalline, grey, reworked juvenile lava up to $30 \mathrm{~cm}$ across, variably non-vesicular and coarsely vesicular, plus coarsely vesicular bombs with glassy rims, some deformed (Fig. 9a). The summit outcrops, c. $3 \mathrm{~km}$ to the south-west at c. $2570 \mathrm{~m}$ asl, consist of sparse outcrops of yellow fine lapilli tuff similar to those of the north side but better stratified (Fig. 9b) and much richer in sideromelane tuff matrix (c. 80-95\% compared with c. 10-20\% in the basal outcrops). The sideromelane fragments in these upper outcrops are predominantly vesicular and cuspate. The deposits also contain locally numerous highly vesicular dark grey bombs $15-20 \mathrm{~cm}$ in diameter. Alteration in the summit area is greater than below, with much more pervasive palagonite, and zeolite infills pore spaces and vesicles. The summit area is also strewn with numerous loose blocks of lava, multicoloured in bright pink, rusty brown and cream hues due to extensive hydrothermal alteration to albite and jarosite or alunite (Fig. 9c). In thin section, the lava blocks are seen to be composed of hematite-altered glass with quench-textured feldspar microlites, and a few olivine phenocrysts.

An abrupt transition up into finely crystalline pale grey lava with maroon scoriaceous margins occurs at $\mathrm{c}$. 60-80 $\mathrm{m}$ above the granitoid base of the sequence. The lava consists of poorly seen small pāhoehoe lobes. The lavas in the vertical cliff at the top of Sheridan Bluff comprise sheets and lobes of crystalline grey pāhoehoe with maroon sometimes ropy-textured surfaces lacking glassy rims (Fig. 9d), and similar lithofacies form the scree below. The lava lobes thicken upward in the sequence and the thicker lobes are coarsely and crudely columnar jointed (columns c. $1 \mathrm{~m}$ in diameter). The surface of the lava outcrop, extending south-west towards the summit area, is greatly broken up and comprises a blockfield of poorly to moderately vesicular lava-rubble; some loose lava blocks contain very coarse spherical to more rarely flattened vesicles up to $8 \mathrm{~cm}$ wide and $4 \mathrm{~cm}$ high, occasionally forming vesicle zones separated by non-vesicular lava. The surface is undulating, probably reflecting original tumuli, with scattered low lava crags up to $4 \mathrm{~m}$ high formed of single lava lobes. It has a gentle, probably near-original dip (c. $10-5^{\circ}$ ) to the east-northeast (Fig. 8a). Traced up-dip to the south-west, the surface transforms to an extensive field of linear patterned ground formed of more finely broken lava debris. Minor granitoid and rarer Beacon sandstone erratics are scattered on the lava surface.

Based on measured GPS elevations, the exposed volcanic sequence is c. $160 \mathrm{~m}$ thick at the north-eastern end of 
Fig. 8 (a) Geological outcrop map of Sheridan Bluff and its hinterland (after Smellie et al. 2021b, modified). (b) View of Sheridan Bluff with the geology indicated. Elevations shown in both diagrams are by hand-held GPS with altimeter calibration

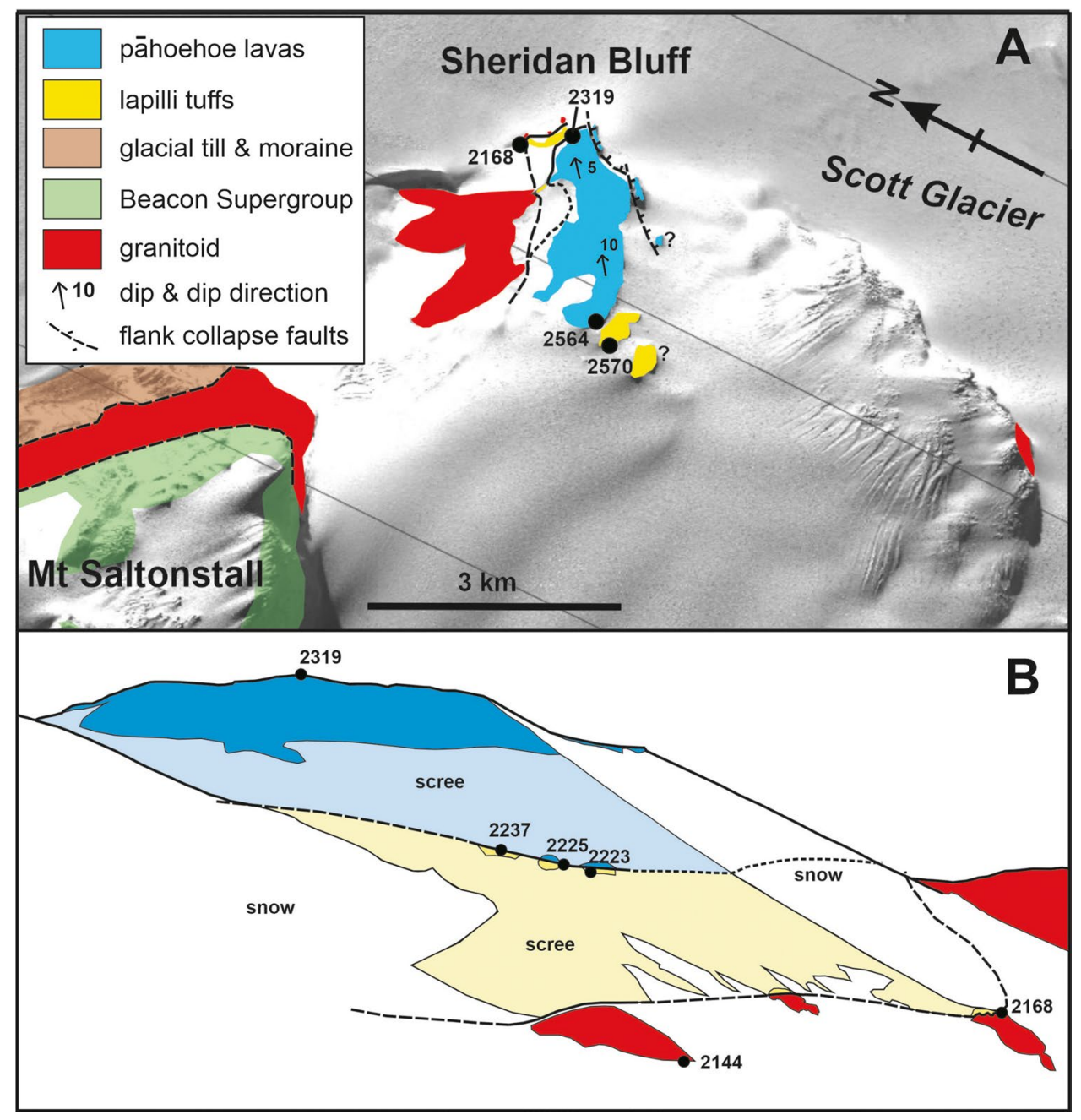

the outcrop (i.e. Sheridan Bluff, s.s.) but a total minimum thickness of $>400 \mathrm{~m}$ is possible between the exposed base at Sheridan Bluff and the summit outcrops to the south-west; the maximum thickness of lavas exposed above lapilli tuffs is c. $100 \mathrm{~m}$.

Interpretation The earliest rocks erupted at Sheridan Bluff may be represented by numerous loose lava blocks scattered on the summit outcrops of lapilli tuff. The lavas show evidence for original glass (now altered) and quench textures, which suggest that they may be fragments of pillow lava incorporated in the lapilli tuffs during explosive ejection, then weathered out more or less in situ; pillow lavas are unknown in the local basement geology (Minshew 1967). The blocks might therefore be evidence for a pillow lava core deep within the volcano but which is currently unexposed (Fig. 10a).

The lapilli tuffs (LT1) at Sheridan Bluff are similar to those described for Mt Early. They are characteristic of deposits formed during explosive hydrovolcanic eruptions and transported in pyroclastic density currents (see Table 1). The presence of scarce bombs in the lower outcrops, with thin glassy chilled selvages, suggests that the bombs may have erupted subaerially but were chilled falling through water. The absence of bedrock (granitoid) fragments suggests that the magma was interacting with surface water rather than groundwater. Hydrovolcanic eruptions in shallow water (much less than $100 \mathrm{~m}$ ) often construct tuff rings although tuff cones may also be constructed (White 1996; Belousov and Belousova 2001). However, the sparse indication of a possible pillow mound core, if present, might suggest water depths of 100-200 m at the outset of eruptions since hydrovolcanic explosivity to yield lapilli tuffs with the characteristics of LT1 (Table 1) becomes less likely below that (Zimanowski and Büttner 2003), although the transition depth is imprecise and not yet a fully settled question. The basal outcrops of LT1 are also better sorted, with numerous empty pore spaces and minor very fine tuff matrix, suggesting winnowing and bypassing of finer ash during transport and deposition in water (see previous comments for $\mathrm{Mt}$ Early). Winnowing from an associated subaerial eruption 
Fig. 9 Compendium of lithofacies characteristic of Sheridan Bluff. (a) Type 1 lapilli tuffs with several bombs (mainly above ice axe); lower exposures at Sheridan Bluff; the ice axe head is $25 \mathrm{~cm}$ in length. (b) Fine ash-rich type 1 lapilli tuffs showing disturbed fine stratification; summit outcrop. (c) Intensely altered lava clast (likely pillow fragment) lying loose on the summit outcrop; the lens cap is $6 \mathrm{~cm}$ in diameter. (d) View of pāhoehoe lavas with oxidised and sometimes ropy surfaces and crude coarse prismatic columns c. $1 \mathrm{~m}$ in diameter
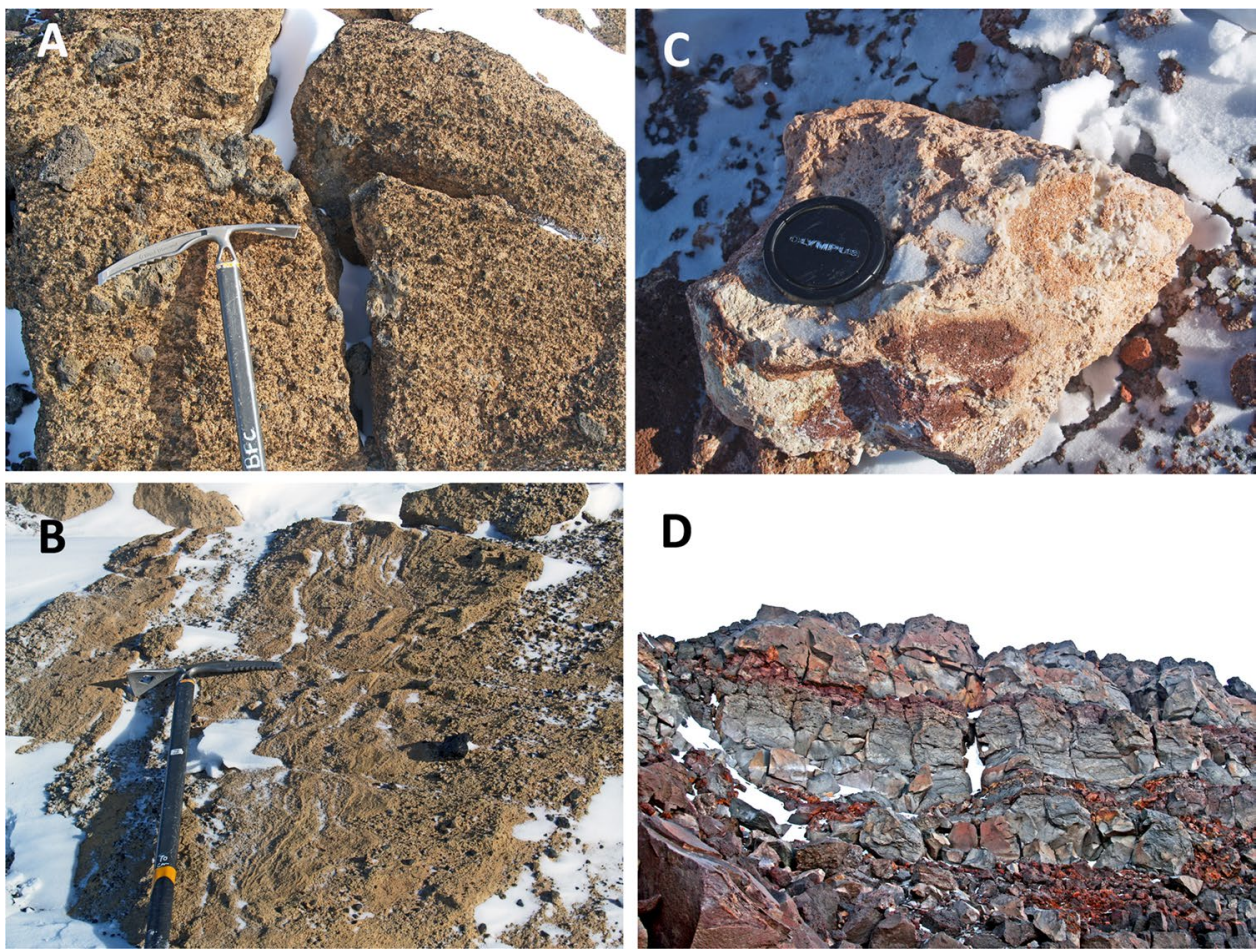

column might also reduce the proportion of fine ash. The summit outcrops are much richer in fine tuff matrix, are poorly sorted, locally contain numerous vesicular bombs, and they crop out at a similar elevation to the surrounding pāhoehoe lavas, indicating that the summit lapilli tuffs were vented and deposited subaerially, whilst hydrovolcanic. Moreover, the presence of red (oxidised) scoria in the lapilli tuffs cropping out immediately below lavas at Sheridan Bluff itself suggests that Strombolian eruptions may have taken place briefly before lava effusion, with some of the scoria reworked by reinstated hydrovolcanic eruptions. The lavas are typical pāhoehoe erupted under essentially dry subaerial conditions, with surface tumuli and zones of round or ovoid vesicles characteristic of flow inflation, and no obvious evidence for water interaction. Thus, the pyroclastic cone summit area was subaerial prior to lava effusion.

Since lavas must flow downhill under gravity and there is no evidence for regional tilting, the original crater (now removed by erosion) must have been situated upslope to the south-west. The summit outcrops of lapilli tuff and associated loose lava blocks are extensively hydrothermally altered signifying enhanced geothermal gradients. They are therefore probably situated close to the vent for the volcanic centre. The morphology of the original volcano can now be deduced. Assuming it was symmetrical, it probably had an original diameter of c. $6 \mathrm{~km}$ (Fig. 10b). In the scenario depicted, it is clear that perhaps only $<15 \%$ is now exposed of what was probably a small volcano with a shield-like morphology composed of a pyroclastic core and lava carapace (Fig. 9). The low apparent dip of the lava-draped flank presumably must reflect that of the underlying tephras. It is similar to that of tuff rings (Broz and Németh 2015). However, tuff rings are smallvolume volcanic edifices $\left(<<1 \mathrm{~km}^{3}\right)$ with a short eruption duration (typically hours to days). Beds are seldom traceable more than $1 \mathrm{~km}$ away from the crater rim, they often include conspicuous dune beds and abundant bedrock-derived clasts, a pillow lava core is absent, crater rim heights are typically $<100 \mathrm{~m}$ and crater floor elevations are close to that of the surrounding landscape (Sohn 1996; Broz and Németh 2015). By contrast, the reconstructed Sheridan Bluff centre (Fig. 10b) would have had a substantial volume estimated as c. $4.2 \mathrm{~km}^{3}$ for the entire edifice above the exposed base, including the lava carapace; the equivalent volume for the pyroclastic cone is c. $3.7 \mathrm{~km}^{3}$. Moreover, its flanks extended $\geq 3 \mathrm{~km}$, dune beds were not observed, bedrock-derived clasts are scarce, pillow lava may be present (although inferred and not exposed) and the crater floor must have been at an elevation of $>400 \mathrm{~m}$ (cf. Brand and Broz 2015). Taken together, the characteristics of the pyroclastic core of the edifice at Sheridan Bluff are more similar to a tuff cone. Finally, the presence of bench-like steps on the north-east flank (Fig. 10b) suggests that local (and very much younger) collapse of that flank has taken place, probably caused by erosion and oversteepening by a 'palaeo-Scott Glacier' during younger glacials, alternating with loss of ice support in intervening ice-poor periods. 
Fig. 10 (a) Schematic true-scale cross section of Sheridan Bluff.

The vertical scale indicates metres above the exposed base of the volcano. The existence of a small pillow mound core is inferred based on the presence of water-chilled lava clasts in lapilli tuffs interpreted as fragmented lava pillows (see text for description). The location of the hypothetical line of section (A-A') is shown in (b). (b) Schematic reconstruction of Sheridan Bluff volcano. Compare with Fig. 8a. The darker colours represent exposed rock; paler shades represent inferred sub-ice outcrop

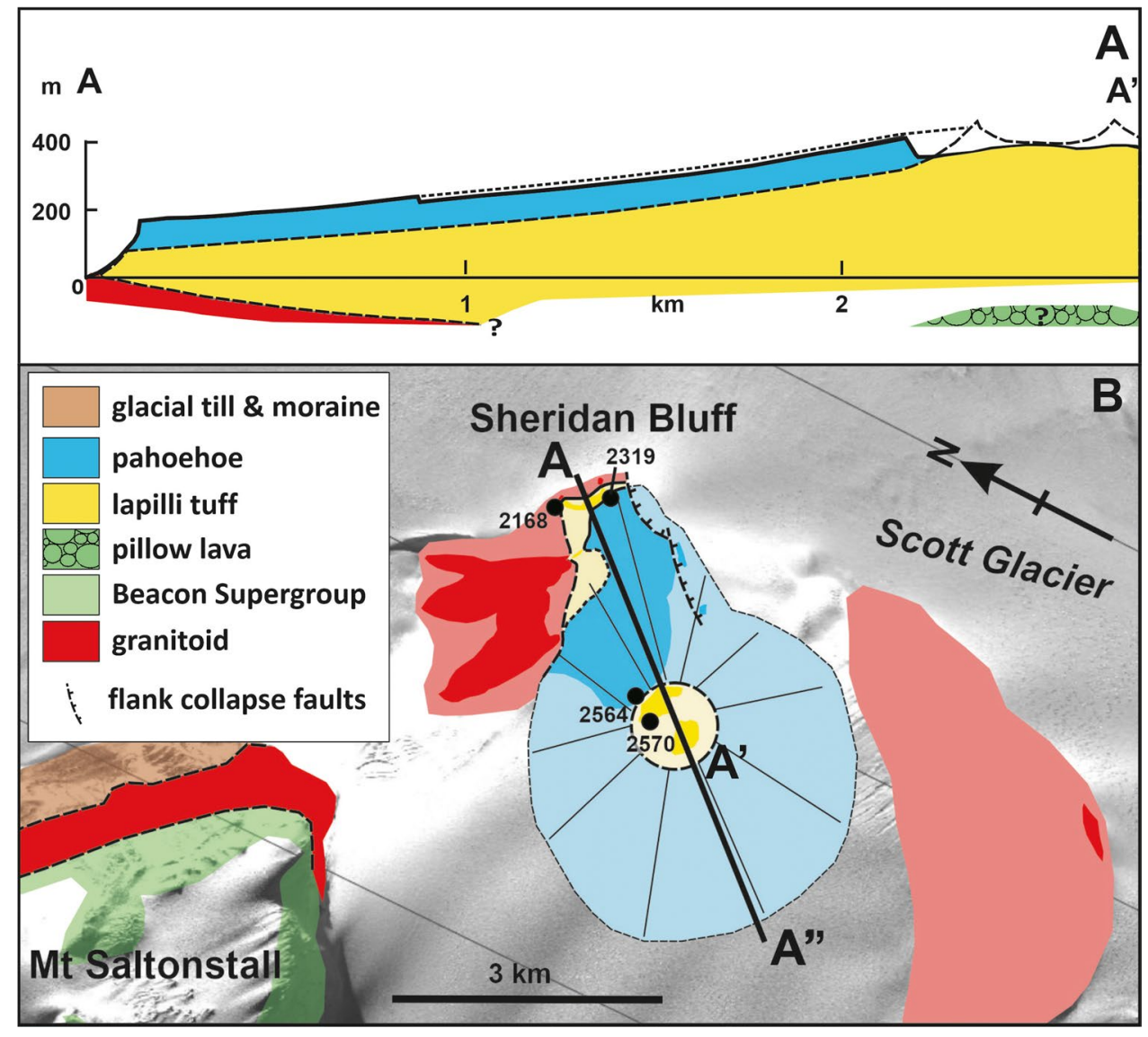

\section{Discussion-eruptive palaeoenvironments}

\section{Mt Early}

As described above, subglacial eruption of Mt Early is evident and we can now estimate the contemporaneous palaeoice thicknesses. The nunatak is surrounded by ice that is c. $500 \mathrm{~m}$ thick (estimated from BEDMAP; Fretwell et al. 2013) and it reaches a summit elevation c. $450 \mathrm{~m}$ above the present ice surface. The feature is therefore c. $1000 \mathrm{~m}$ high today. However, Mt Early has been extensively modified, probably by overriding ice. Its base is unexposed and no crater is preserved on the summit. The flanks are also extensively eroded so the original dimensions, including the height of the centre, are unknown. Although the thinness of the capping tephra pile at Mt Early suggests that the final explosive episode was relatively brief, much of the tephra may have been removed, probably soon after cessation of volcanic activity when the tephra was still relatively soft and easily eroded. Explosively generated hydrovolcanic tephra can form tuff cones extending up to a few hundred metres above the contemporary water surface. Therefore, the explosive period could have been much longer and the volcano may have been much taller originally. It is likely that the summit of the Mt Early volcano was visible protruding above the contemporaneous ice surface. During eruptions, the ice surface surrounding a warm volcanic centre would have been affected by drawdown. Up to c. $150 \mathrm{~m}$ of drawdown has been observed in other glaciovolcanic eruptions, and the ice surface would be higher by that amount outside of the drawdown area (Gudmundsson 2002; Edwards et al. 2015, Fig. 20.3). This implies a conservative estimate of c. $3000 \mathrm{~m}$ asl (relative to present datum) for the elevation of the coeval ice surface (i.e. Mt Early summit elevation plus $150 \mathrm{~m}$ ). Eruptions under such substantial ice thicknesses create glaciovolcanoes with pillow bases and tuff cone summits (e.g. Jones 1969; Edwards et al. 2015; Smellie and Edwards 2016).

Mt Early is currently situated at the head of Scott Glacier. The significantly higher ice surface elevation calculated for the Early-mid Miocene eruptive episode indicates that the surrounding topography would have been drowned by ice and the palaeo-Scott Glacier would have been an ice stream or outlet glacier at that time. Because the bedrock topography is not well constrained for the Early-mid Miocene, it is not possible to distinguish between an ice stream and an outlet glacier but it is referred to here as an ice stream because the contemporaneous topography was covered by ice. Ice streams or outlet glaciers are relatively fast-moving compared to other grounded ice. They move at rates that 
vary from a few hundred metres to a few kilometres per year (Rignot et al. 2011).

An ice stream flowing past Mt Early would have exerted a compressive stress on the stoss side of the relatively warm (active) volcanic edifice, causing erosion and enhanced meltwater generation due to pressure effects of the moving ice pressing against rock (cf. analogue experiments by Cole et al. 2021). A cavity would also have formed on the lee side if the tensile stress due to the speed of ice flow around the volcano exceeded the ability of the ice to close the cavity due to normal cryostatic pressure. Thus, the ice would have split and flowed around the volcanic obstacle, probably with separation points on its flanks (Fig. 11). Recombination would have occurred downstream on the lee side of the volcano, resulting in the creation of an elongate englacial cavity filled by meltwater (cf. Bennett et al. 2006). There would thus have been no buttressing support of ice on that flank and the cavity could also act as a local depocenter for debris from sector collapses (Fig. 11). This should lead to an asymmetrical volcanic edifice aligned with the ice flow vector. Since ice streams are characteristically wet based, the supply of meltwater into the englacial lake, increased by pressuremelting on the stoss side, is likely to have increased the subglacial discharge, thus lubricating and enhancing basal slip of the glacier. This would probably have resulted in a local lee-side drawdown of the ice surface together with increased crevassing (Fig. 11). We also speculate that the greater stoss side erosion implied by our model should lead to lithofacies of the pillow lava core being preferentially exposed on the south or south-west (upstream) side. It is currently obscured by snow and ice. By contrast, the absence of ice support on the lee side should have promoted collapses of that flank throughout the eruptive period, and is where volcaniclastic rocks would be preferentially preserved. The likelihood of preserving a larger proportion of the relatively soft lapilli tuff carapace is also higher on the protected lee side.

Previous interpretations of glaciovolcanic edifices have assumed an essentially static ice cover and the characteristics of glaciovolcanoes erupted through fast-moving ice streams have not been described previously. However, it is suggested that stresses exerted by the moving ice stream during the eruption could have been responsible for the unusually widespread deformation seen at Mt Early. Moreover, based on our interpretation, the combination of pervasive shearing, multiple mass flow deposits draping the lee side as a result of repeated sector collapses, an asymmetrical volcano profile with pillow lavas exposed on the (more eroded) stoss side and weaker volcaniclastic rocks preserved preferentially on the (protected) lee side is distinctive and may be diagnostic.

No evidence was seen for subaerial capping lavas at Mt Early, although they were postulated (but unvisited) by Stump et al. (1980, 1990b). The highest outcrop of grey columnar lava, which might easily have been mistaken for subaerial lava, crops out below orange lapilli tuffs (LT1) and is probably intrusive (Fig. 4a). However, the lithofacies suggest that there was a volumetrically minor third eruptive stage at Mt Early, and there is no evidence for a significant time break with the earlier eruptive activity. The youngest rocks present are crystalline grey columnar lava and associated dark grey scoria and agglutinate that intrude LT1 and pillow lava/hyaloclastite. The absence of any evidence for water interaction in these rocks (i.e. presence of fully crystalline lava, slowly cooled columnar joints, agglutinate, and absence of glass and hyaloclastite) and the presence of maroon oxidised scoria reworked into the, admittedly rare, high-level polymict lapilli tuff lithofacies (pLT; Table 1), suggest that the eruptions associated with the grey columnar lava took place under drier ambient conditions. It is postulated that the younger rocks were emplaced when the vent within the volcanic pile had dried out, implying that the

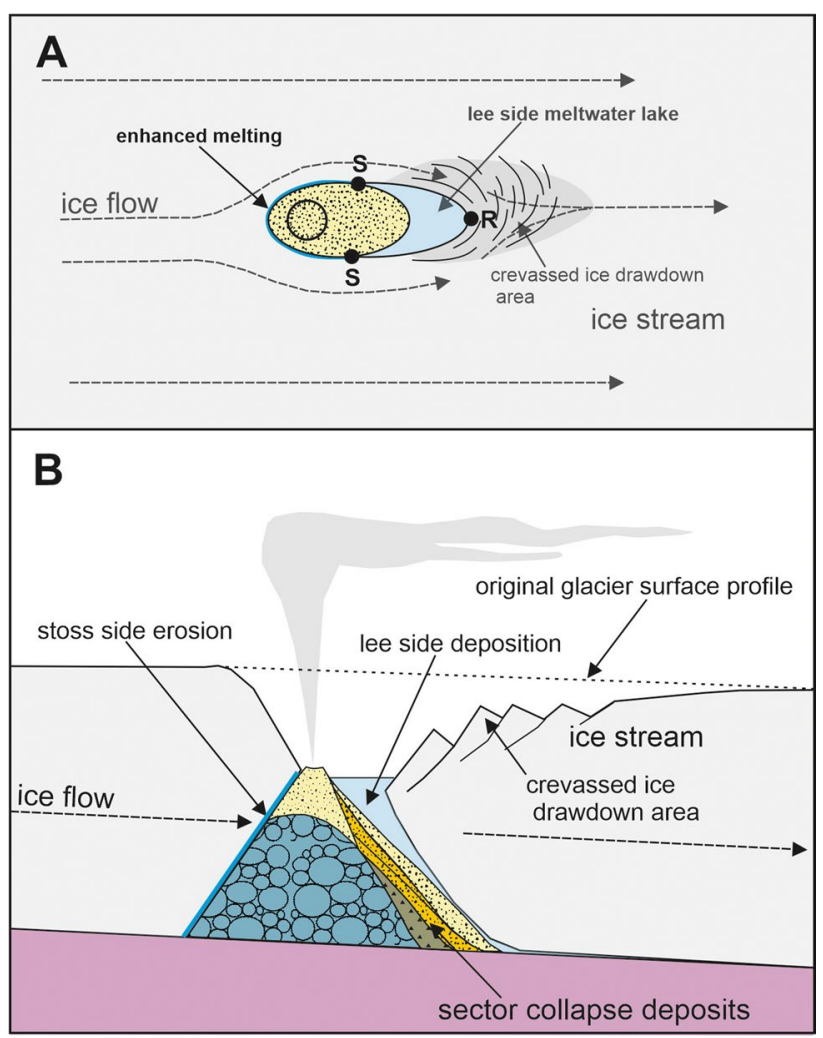

Fig. 11 Schematic plan view (a) and cross section (b) reconstructions of the Mt Early volcano showing inferred ice flow in Early Miocene time. Glacial erosion would have occurred on the upstream (stoss) side and a meltwater-filled cavity developed on the downstream (lee) side, probably associated with a particularly crevassed surface on the lee side due to ice drawdown caused by fast ice stream flow around the edifice. The removal of buttressing ice support for the englacial edifice on its lee side would have promoted flank instability, resulting in sector collapses and accumulation of successive massive mass flow deposits in the englacial cavity. $\mathrm{S}$ - separation points; $\mathrm{R}$ - recombination point. Not to scale 
water-filled vault associated with the earlier pillow lava and lapilli tuff activity may have drained. The eruption of oxidised scoria and agglutinate suggests that at least some of these late-stage eruptions were subaerial. Emplacement of the intrusive masses may also have contributed to destabilisation by inflating the volcanic pile, triggering at least some of the conspicuous deformation observed.

\section{Sheridan Bluff}

That ice existed at some time prior to the eruption of the Sheridan Bluff volcano is demonstrated by the presence of striations on the underlying granitoid basement. The evidence of striations and ice moulding of the granitoid surface, and an assumed similarity to 'moberg' volcanoes in Iceland (tuyas?), strongly influenced Stump et al. (1980) in their interpretation of a glacial setting for the eruptions. The striations are orientated perpendicular to the rock face and trend under the lapilli tuffs; they were therefore not caused by a modern glaciation. However, evidence for ice on a prevolcanic bedrock surface only proves that ice existed at that location prior to the volcanic eruptions. It does not necessarily follow that the eruptions themselves were glaciovolcanic (Smellie and Edwards 2016; Smellie 2018). Furthermore, the presence of granitoid and Beacon sandstone erratics on the outcrop, and its eroded state, indicates that Sheridan Bluff has been overridden by ice since its formation. Thus, the volcano formed between two glacial episodes, although their ages are unknown. Similar to the reasoning advanced for Mt Early, the presence and characteristics of lapilli tuffs (LT1) at Sheridan Bluff indicate explosive hydrovolcanic eruptions, probably within a lake (glacial or pluvial). From the rare presence of quenched lava clasts in the summit region, which may be fragments of pillow lava, it is possible that initial eruptions were effusive and the volcano has a pillow lava mound in its core. Based on the location of Sheridan Bluff, far inland and at high elevation (>2200 m asl), eruptions within the sea are unrealistic. However, unlike at Mt Early, the volcanic sequence at Sheridan Bluff occupies a laterally extensive, topographical hollow eroded in granitoid bedrock, which might easily have ponded surface water in a pluvial lake. The putative lake had a minimum depth of $50 \mathrm{~m}$ based on the thickness of water-deposited(?) lapilli tuffs exposed at Sheridan Bluff itself. The shape of the granitoid bedrock is only exposed at its northern margin and its precise morphology beneath the volcano is unknown. However, if a pillow lava mound is present, coeval water depths might have been significantly deeper (possibly $\geq 100-200 \mathrm{~m}$ ).

Although the Sheridan Bluff volcano is probably dominated by a hydrovolcanic tuff cone core formed of lapilli tuffs (LT1) draped by subaerial pāhoehoe lava (Fig. 10a), the overall morphology of the reconstructed edifice is not obviously glaciovolcanic. Morphometric studies have demonstrated that subglacially erupted volcanic centres typically have high aspect ratios (height:width; Smellie 2013; Pedersen et al. 2020). This probably also includes glaciovolcanic tuff cones (and analogous ridges known as tindars), although there are fewer published data (unpublished information of JS). By contrast, the Sheridan Bluff volcano was a monogenetic volcano with a low surface gradient. There appears to be no way to reconstruct a similar morphometry in a glaciovolcanic context and the observations much more closely resemble the profiles of volcanoes erupted in unconfined marine or lacustrine situations. We use a young (c. $660 \mathrm{ka}$ ) marine-erupted, Surtseyan pyroclastic cone (Terrapin Hill) from James Ross Island, Antarctica, as a similar-sized reference example of a volcano erupted in an unconfined setting (described by Smellie et al. 2006). When the two volcano profiles are superimposed, the close correspondence between the surface slopes is striking, with the mismatches explained principally as a consequence of glacial erosion of the lower flanks of the Pleistocene Terrapin Hill volcano, and the greater elevation of its summit (Fig. 12). The reason for the relatively low gradient of the flanks of the Sheridan Bluff pyroclastic cone compared to other tuff cones is uncertain but we note that an unknown amount of glacial erosion of the summit region, with its potentially steepest gradients, has occurred at Sheridan Bluff. Thus, we suggest that the eruptive setting of the Sheridan Bluff volcano was unconfined. Because the eruptions could not have been marine, the environment was therefore a pluvial lake. It was thus ice poor or conceivably ice free.

\section{Summary}

Several small mafic volcanic centres are present in the southern Transantarctic Mountains between 85 and $87^{\circ} \mathrm{S}$, within $300 \mathrm{~km}$ of South Pole, although only two are currently exposed (Mt Early and Sheridan Bluff). They are the southernmost volcanoes in the world and have Early-mid Miocene published isotopic ages. Both were previously interpreted as glaciovolcanic. From a study of the lithologies, lithofacies and architecture, a history of very different eruptive settings is evident. Although both volcanoes are Surtseyan (i.e. shoaling to emergent centres), only Mt Early is unequivocally glaciovolcanic. It erupted under a thickerthan-modern ice sheet that was probably an ice stream at the eruptive site. By contrast, the Sheridan Bluff centre cannot be forced to fit into any glaciovolcanic model, and unconfined eruption within a pluvial lake is indicated. Our study demonstrates, yet again, that volcanic studies can be used to tease out important environmental information that cannot be obtained any other way. 


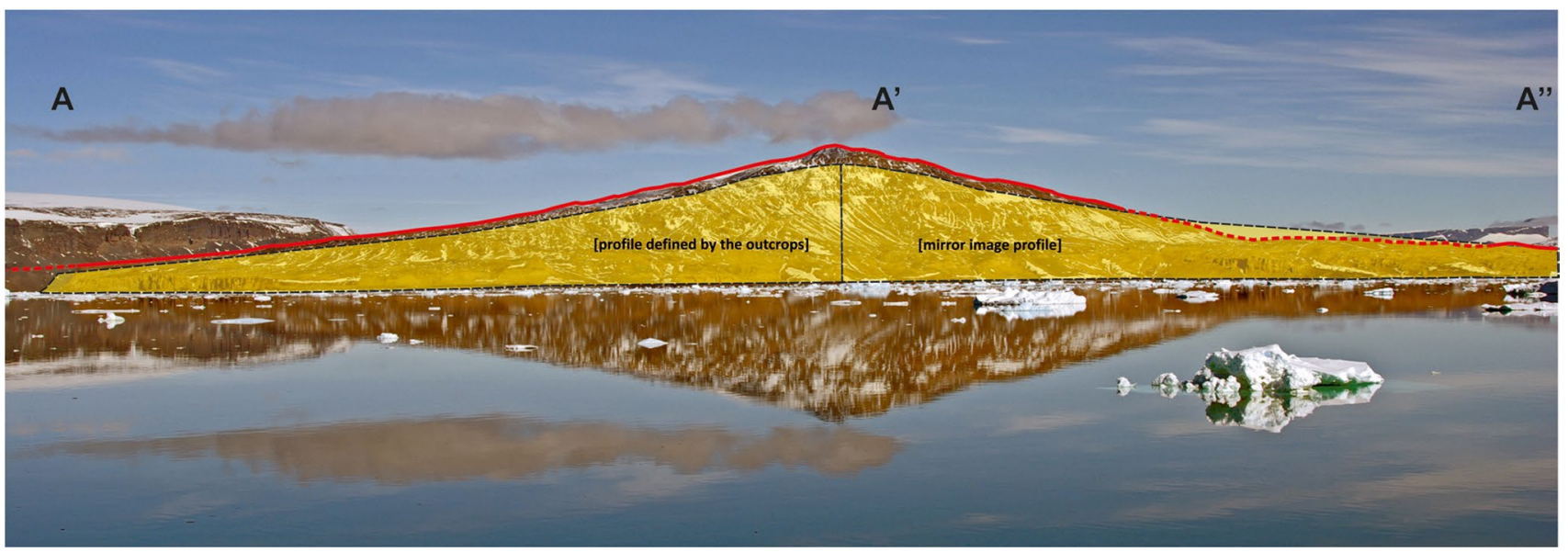

Fig. 12 Comparison of true-scale profiles of a marine-erupted pyroclastic volcano (Terrapin Hill, Antarctica; see Smellie et al. 2006, for description) and the pyroclastic stage of the Sheridan Bluff volcano (yellow coloration). The red line is used to emphasise the Terrapin Hill profile, to ease comparison. Only one flank of the Sheridan Bluff volcano is exposed and the whole-volcano profile has been reconstructed using a mirror image. The similarity in surface gradients between the two volcanoes is remarkable, with the only significant

Acknowledgements Ed Stump was particularly generous in providing us with photographs of the volcanic outcrops at Mt Early and Sheridan Bluff from his 1978 expedition and with local information that helped us to prepare our proposal [NSF PLR 1443576] and also to conduct the fieldwork, for which we are very grateful. We are also grateful to NSF and all the NSF staff at Christchurch, McMurdo Station and the Shackleton Glacier transit camp for the excellent logistical and other support. We thank Kathy Licht for comments on an early draft, Tim Burton for his highly professional field assistance and Jenna Reindel who also helped with the fieldwork. JS is very grateful to Annika Burns (Leicester University) for her preparation of many of the thin sections used in this study, often from materials with difficult sectioning characteristics. Finally, the authors are also grateful to Kelly Russell and Chris Conway for their reviews of this paper, and to Pierre-Simon Ross for his painstakingly thorough review and editing.

Open Access This article is licensed under a Creative Commons Attribution 4.0 International License, which permits use, sharing, adaptation, distribution and reproduction in any medium or format, as long as you give appropriate credit to the original author(s) and the source, provide a link to the Creative Commons licence, and indicate if changes were made. The images or other third party material in this article are included in the article's Creative Commons licence, unless indicated otherwise in a credit line to the material. If material is not included in the article's Creative Commons licence and your intended use is not permitted by statutory regulation or exceeds the permitted use, you will need to obtain permission directly from the copyright holder. To view a copy of this licence, visit http://creativecommons.org/licenses/by/4.0/.

\section{References}

Barrett PJ, Ricci CA (2001) Studies from the Cape Roberts Project, Ross Sea, Antarctica. Scientific Report of CRP-3. Terra Antartica $8: 1-620$ mismatches attributed to localised glacial erosion of the northern (right side) flank of Terrapin Hill and its higher summit region. Such low-gradient volcano profiles cannot be reproduced in a confined eruption, i.e. under an ice sheet. Eruption in an unconfined setting (i.e. a pluvial lake) is indicated. Note that the contemporaneous water levels associated with both volcanoes would have been higher than that shown in the photograph. A, A' and A'" refer to the hypothetical line of section shown in Fig. 10b

Behrendt JC, Blankenship DD, Morse DL, Finn CA, Bell RE (2002) Subglacial volcanic features beneath the West Antarctic Ice Sheet interpreted from aeromagnetic and radar ice sounding. In: Smellie JL, Chapman MG (eds) Volcano-ice interaction on Earth and Mars. Geol Soc Lond Sp Publ 202: pp. 337-355

Belousov A, Belousova M (2001) Eruptive process, effects and deposits of the 1996 and the ancient basaltic phreatomagmatic eruptions in Karymskoye lake, Kamchatka, Russia. In: White JDL, Riggs $\mathrm{N}$ (eds) Lacustrine volcaniclastic sedimentation. IAS Spec Publ 30: pp. 73-98

Bennett MR, Huddart D, Waller RI (2006) Diamict fans in subglacial water-filled cavities-a new glacial environment. Quat Sci Rev 25:3050-3069

Brand BD, Broz P (2015) Tuff cone. In: Hargitai H, Kereszturi Á (eds) Encyclopedia of planetary landforms, vol 3, Springer Science+Business Media LLC New York, ISBN 978-14614-3133-6, https://doi.org/10.1007/978-1-4614-3134-3: pp. 2197-2204

Brand BD, Clarke AB (2009) The architecture, eruptive history, and evolution of the Table Rock Complex, Oregon: from a Surtseyan to an energetic maar eruption. J Volcanol Geotherm Res 180:203-224

Branney MJ, Kokelaar P (2002) Pyroclastic density currents and the sedimentation of ignimbrites. Geol Soc Lond Mem 27:1-143

Brown RJ, Bonadonna C, Durant AJ (2012) A review of ash aggregation. Phys Chem Earth 45-46:65-78

Brown RJ, Branney MJ, Maher C, Dávila-Harris P (2010) Origin of accretionary lapilli within ground-hugging density currents: evidence from pyroclastic couplets on Tenerife. Geol Soc Am Bull 122:305-320

Broz P, Németh K (2015) Tuff ring. In: Hargitai H, Kereszturi Á (eds) Encyclopedia of planetary landforms, vol 3, Springer Science+Business Media LLC New York, ISBN 978-14614-3133-6, https://doi.org/10.1007/978-1-4614-3134-3: pp. 2204-2210

Cas RAF, Landis CA, Fordyce RE (1989) A monogenetic, Surtla-type, Surtseyan volcano from the Eocene-Oligiocene 
Waiareka-Deborah volcanics, Otago, New Zealand: a model. Bull Volcanol 51:281-298

Cole PD, Guest JE, Duncan AM, Pacheco J-M (2001) Capelinhos 1957-1958, Faial, Azores: deposits formed by an emergent surtseyan eruption. Bull Volcanol 63:204-220

Cole R, White J, Dürig T, Büttner R, Zimanowski B, Bowman M, Conway C, Leonard G, Pure L, Townsend D (2021) Controls on Andesitic glaciovolcanism from field and experimental studies. Geology 49, https://doi.org/10.1130/G48735.1

Davis MB, Blankenship DD (2005) Geology of the Scott - reedy glaciers area, southern Transantarctic Mountains, Antarctica. Map and Chart Series, The Geological Society of America MCH093

Doumani GA, Minshew VH (1965) General geology of the Mount Weaver area, Queen Maud Mountains. In: Hadley, J.B. (ed.) Geology and paleontology of the Antarctic. American Geophysical Union, Antarctic Research Series, 6: pp. 127-139

Duncan AM, Chester DK, Guest JE (1984) The Quaternary stratigraphy of Mount Etna, Sicily: the effects of differing palaeoenvironments on styles of volcanism. Bull Volcanol 47:497-516

Edwards BR, Skilling IP, Cameron B, Haynes C, Lloyd A, Hungerford HD (2009) Evolution of an englacial ridge: Pillow Ridge tindar, Mount Edziza volcanic complex, NCVP, British Columbia, Canada. J Volcanol Geotherm Res 185:251-275

Edwards BR, Gudmundsson MT, Russell JK (2015) Glaciovolcanism. In: Sigurdsson H, Houghton B, Rymer H, Stix J, McNutt S (eds) The encyclopedia of volcanoes. Academic Press, London, pp 377-393

Fielding CR, Browne GH, Field B (2011) Sequence stratigraphy of the ANDRILL AND-2A drillcore, Antarctica: a long-term iceproximal record of Early to Mid-Miocene climate, sea-level and glacial dynamism. Palaeogeography, Palaeoclimatology, Palaeoecology 305:337-351

Fretwell P, Pritchard HD, Vaughan DG (2013) Bedmap2: improved ice bed, surface and thickness datasets for Antarctica. The Cryosphere 7:375-393

Gasson E, DeConto RM, Pollard D, Levy RH (2016) Dynamic Antarctic icesheet during the early to mid-Miocene. PNAS 113:3459-3464

Granot, R, Dyment, J (2018) Late Cenozoic unification of East and West Antarctica. Nat Comm https://doi.org/10.1038/ s41467-018-05270-w

Gudmundsson MT (2002) The hyaloclastite ridge formed in the subglacial 1996 eruption in Gjálp, Vatnajökull, Iceland: present day shape and future preservation. In: Smellie JL, Chapman MG (eds) Volcano-ice interaction on Earth and Mars. Geol Soc Lond Sp Publ 202: pp. 319-335

Irvine TN, Baragar WRA (1971) A guide to the chemical classification of the common volcanic rocks. Can Jl E Sci 8:523-548

Iverson NA, Lieb-Lappen R, Dunbar NW, Obbard R, Kim E, Golden E (2017) The first physical evidence of subglacial volcanism under the West Antarctic Ice Sheet. Sci Rep 7:11457. https:// doi.org/10.1038/s41598-017-11515-3

Jones JG (1969) Intraglacial volcanoes of the Laugarvatn region, south-west Iceland-I. J Geol Soc Lond 124:197-211

Le Bas MJ, Le Maitre RW, Streckeisen A, Zanettin B (1986) Chemical classification of volcanic rocks based on the total alkalisilica diagram. J Petrol 27:745-750

LeMasurier WE (2008) Neogene extension and basin deepening in the West Antarctic rift inferred from comparisons with the East African rift and other analogs. Geology 36:247-250

LeMasurier WE, Thomson JW (eds) (1990) Volcanoes of the Antarctic plate and southern oceans. American Geophysical Union, Antarctic Research Series, 48:1-487

Levy R, Harwood D, Florindo F and 22 authors and the SMS Science Team (2016) Antarctic icesheet sensitivity to atmospheric $\mathrm{CO}_{2}$ variations in the early to mid-Miocene. PNAS 113:3453-3458
Licht KJ, Groth T, Townsend JP, Hennessy AJ, Hemming SR, Flood TP, Studinger M (2018) Evidence for extending anomalous Miocene volcanism at the edge of the East Antarctic craton. Geophys Res Lett 45:3009-3016

Minshew VH (1967) Geology of the Scott Glacier and Wisconsin Range areas, central Transantarctic Mountains, Antarctica. PhD thesis, Ohio State University, 268 p. [unpubl.]

Moore JG, Peck DL (1962) Accretionary lapilli in volcanic rocks of the western continental United States. J Geol 70:182-194

Panter KS (2021) Antarctic volcanism - petrology and tectonomagmatic overview. In: Smellie JL, Panter KS, Geyer A (eds) Volcanism in Antarctica: 200 million years of Subduction, Rifting and Continental Break-up. Geol Soc Lond Mem 55: pp. 43-53

Panter KS, Reindel J, Smellie JL (2021) Mt Early and Sheridan Bluff. II. Petrology. In: Smellie JL, Panter KS, Geyer A (eds) Volcanism in Antarctica: 200 million years of Subduction, Rifting and Continental Break-up. Geol Soc Lond Mem 55: pp. 499-514

Pedersen GBM, Grosse P, Gudmundsson MT (2020) Morphometry of glaciovolcanic edifices from Iceland: Types and evolution. Geomorphology 368 https://doi.org/10.1016/j.geomorph.2020.107334

Quartini E, Blankenship DD, Young DA (2021) Active subglacial volcanism in West Antarctica. In: Smellie JL, Panter KS, Geyer A (eds) Volcanism in Antarctica: 200 million years of Subduction, Rifting and Continental Break-up. Geol Soc Lond Mem 55: pp. 785-803

Rignot E, Mouginot J, Scheuchl B (2011) Ice flow of the Antarctic ice sheet. Science 333:1427. https://doi.org/10.1126/science.1208336

Ross P-S, White JDL (2005) Unusually large clastic dykes formed by elutriation of a poorly sorted, coarser-grained source. J Geol Soc Lond 162:579-582

Russell JK, Edwards BR, Porritt LA (2013) Pyroclastic passage zones in glaciovolcanic sequences. Nature Communications, $4 \mathrm{https}: / /$ doi.org/10.1038/ncomms 2829

Schopka HH, Gudmundsson MT, Tuffen H (2006) The formation of Helgafell, southwest Iceland, a monogenetic subglacial hyaloclastite ridge: sedimentology, hydrology and volcano-ice interaction. J Volcanol Geotherm Res 152:359-377

Shen W, Wiens DA, Stern T, Anandakrishnan S, Aster RC, Dalziel I (2018) Seismic evidence for lithospheric foundering beneath the southern Transantarctic Mountains, Antarctica. Geology 46:71-74

Siddoway C (2008) Tectonics of the West Antarctic Rift System: new light on the history and dynamics of distributed intracontinental extension. In: Cooper AK, Barrett PJ, Stagg H, Storey B, Stump E, Wise W and the 10th ISAES editorial team (eds) Antarctica: a keystone in a changing world. Proceedings of the 10th International Symposium on Antarctic Earth Sciences. Washington, DC: The National Academies Press, pp. 91-114

Siddoway C (2021) The geology of West Antarctica. In: Kleinschmidt $\mathrm{G}$ (ed) The geology of the Antarctic continent. Borntraeger Science Publishers, Stuttgart, pp 87-131

Skilling IP (1994) Evolution of an englacial volcano: Brown Bluff, Antarctica. Bull Volcanol 56:573-591

Skilling IP (2009) Subglacial to emergent basaltic volcanism at Hlöðufell, south-west Iceland: a history of ice-confinement. J Volcanol Geotherm Res 185:276-289

Smellie JL (2001) Lithofacies architecture and construction of volcanoes erupted in englacial lakes: Icefall Nunatak, Mount Murphy, eastern Marie Byrd Land, Antarctica. In: White JDL, Riggs N (eds) Volcaniclastic sedimentation in lacustrine settings. Int Assoc Sedimentol Spec Publ 30: pp. 9-34

Smellie JL (2006) The relative importance of supraglacial versus subglacial meltwater escape in basaltic subglacial tuya eruptions: an important unresolved conundrum. E-Sci Rev 74:241-268

Smellie JL (2008) Basaltic subglacial sheet-like sequences: evidence for two types with different implications for the inferred thickness of associated ice. E-Sci Rev 88:60-88 
Smellie JL (2013) Quaternary vulcanism: subglacial landforms. In: Elias SA (ed) Reference module in Earth Systems and Environmental Sciences, from The Encyclopedia of Quaternary Science, vol 1, 2nd edn. Elsevier, Amsterdam, pp 780-802

Smellie JL (2018) Glaciovolcanism - a $21^{\text {st }}$ century proxy for palaeoice. In: Menzies J, van der Meer JJM (eds) Past glacial environments (sediments, forms and techniques), 2nd edn. Elsevier, Amsterdam, Netherlands, pp 335-375

Smellie JL, Edwards BR (2016) Glaciovolcanism on Earth \& Mars. Products, processes and palaeoenvironmental significance. Cambridge University Press, Cambridge, p 483

Smellie JL, Hole MJ (1997) Products and processes in Pliocene-recent, subaqueous to emergent volcanism in the Antarctic Peninsula: examples of englacial Surtseyan volcano construction. Bull Volcanol 58:628-646

Smellie JL, Rocchi S (2021) Northern Victoria Land I. Volcanology In: Smellie JL, Panter KS, Geyer A (eds) Volcanism in Antarctica: 200 million years of subduction, rifting and continental break-up. Geol Soc Lond Mem 55: pp. 347-381

Smellie JL, Hole MJ, Nell PAR (1993) Late Miocene valley-confined subglacial volcanism in northern Alexander Island, Antarctic Peninsula. Bull Volcanol 55:273-288

Smellie JL, McArthur JM, McIntosh WC, Esser R (2006) Late Neogene interglacial events in the James Ross Island region, northern Antarctic Peninsula, dated by $\mathrm{Ar} / \mathrm{Ar}$ and $\mathrm{Sr}$-isotope stratigraphy. Palaeogeogr Palaeoclimatol Palaeoecol 242:169-187

Smellie JL, Johnson JS, McIntosh WC, Esser R, Gudmundsson MT, Hambrey MJ, van Wyk de Vries B (2008) Six million years of glacial history recorded in the James Ross Island Volcanic Group, Antarctic Peninsula. Palaeogeography, Palaeoclimatology, Palaeoecology 260:122-148

Smellie JL, Haywood AM, Hillenbrand C-D, Lunt DJ, Valdes PJ (2009) Nature of the Antarctic Peninsula Ice Sheet during the Pliocene: geological evidence \& modelling results compared. E-Sci Rev 94:79-94

Smellie JL, Rocchi S, Armienti P (2011a) Late Miocene volcanic sequences in northern Victoria Land, Antarctica: products of glaciovolcanic eruptions under different thermal regimes. Bull Volcanol 73:1-25

Smellie JL, Rocchi S, Gemelli M, Di Vincenzo G, Armienti P (2011b) A thin predominantly cold-based Late Miocene East Antarctic ice sheet inferred from glaciovolcanic sequences in northern Victoria Land, Antarctica. Palaeogeogr Palaeoclimatol Palaeoecol 307:129-149

Smellie JL, Rocchi S, Wilch TI, Gemelli M, Di Vincenzo G, McIntosh WC, Dunbar N, Panter K, Fargo A (2014) Glaciovolcanic evidence for a polythermal Neogene East Antarctic Ice Sheet. Geology 42:39-41

Smellie JL, Rocchi S, Johnson JS, Di Vincenzo G, Schaefer JM (2018) A tuff cone erupted under frozen-bed ice (northern Victoria Land, Antarctica): linking glaciovolcanic and cosmogenic nuclide data for ice sheet reconstructions. Bull Volcanol 80:12. https://doi.org/ 10.1007/s00445-017-1185-X

Smellie JL, Panter KS, Geyer A (eds) (2021a) Volcanism in Antarctica: 200 million years of Subduction, Rifting and Continental Breakup. Geol Soc Lond Mem 55: 824 pp

Smellie JL, Panter KS, Reindel J (2021b) Mt Early and Sheridan Bluff. I. Volcanology. In: Smellie JL, Panter KS, Geyer A (eds) Volcanism in Antarctica: 200 million years of Subduction, Rifting and Continental Break-up. Geol Soc Lond Mem 55: pp. 491-498

Smith GA (1986) Coarse-grained nonmarine volcaniclastic sediment: terminology and depositional processes. Geol Soc Am Bull 97:1-10
Sohn YK (1996) Hydrovolcanic processes forming basaltic tuff rings and cones on Cheju Island, Korea. Bull Volcanol 108:1199-1211

Sohn YK, Cronin SJ, Brenna M, Smith IEM, Németh K, White JDL, Murtagh RM, Jeon YM, Kwon CW (2012) Ilchulbong tuff cone, Jeju Island, Korea, revisited: a compound monogenetic volcano involving multiple magma pulses, shifting vents, and discrete eruptive phases. Geol Soc Am Bull 124:259-274

Staudigel H, Schmincke H-U (1984) The Pliocene seamount series of La Palma/Canary Islands. J Geophys Res 89:11195-11215

Stump E, Sheridan MF, Borg SG, Sutter JF (1980) Early Miocene subglacial basalts, East Antarctic ice sheet, and uplift of the Transantarctic Mountains. Science 207:757-759

Stump E. Borg SG, Sheridan MF (1990a) Sheridan Bluff. In: LeMasurier WE, Thomson JW (eds) Volcanoes of the Antarctic plate and southern oceans. American Geophysical Union, Antarctic Research Series 48: pp. 136-137

Stump E, Borg SG, Sheridan MF (1990b) Mount Early. In: LeMasurier, W.E. and Thomson, J.W. (eds) Volcanoes of the Antarctic plate and southern oceans. American Geophysical Union, Antarctic Research Series 48: pp. 138-139

Sugden DE (1996) The East Antarctic ice sheet: unstable ice or unstable ideas? Trans Inst Brit Geogr 21:443-454

van Wyk de Vries M, Bingham RG, Hein AS (2018) A new volcanic province: an inventory of subglacial volcanoes in West Antarctica. Geol Soc Lond Sp Publ 461:231-248

Watts AB, Peirce C, Grevemeyer I, Paulatto M, Stratford W, Bassett D, Hunter JA, Kalnins LM, de Ronde CEJ (2012) Rapid Rates of Growth and Collapse of Monowai Submarine Volcano in the Kermadec Arc. Nature Geosc 5:510-515. https://doi.org/10.1038/ ngeo1473

White JDL (1996) Pre-emergent construction of a lacustrine basaltic volcano, Pahvant Butte, Utah (USA). Bull Volcanol 58:249-262

White JDL (2000) Subaqueous eruption-fed density currents and their deposits. Precambr Res 101:87-109

White JDL, Houghton BF (2006) Primary volcaniclastic rocks. Geology 34:677-680

Wilch TI, McIntosh WC (2000) Eocene and Oligocene volcanism at Mt. Petras, Marie Byrd Land: implications for middle Cenozoic icesheet reconstructions in West Antarctica. Antarct Sci 12:477-491

Wilch TI, McIntosh WC (2002) Lithofacies analysis and 40Ar/39Ar geochronology of ice-volcano interactions at Mt. Murphy and the Crary Mountains, Marie Byrd Land, Antarctica. In: Smellie JL, Chapman MG (eds) Volcano-ice interaction on Earth and Mars. Geol Soc Lond Sp Publ 202: pp. 237-253

Wilch TI, McIntosh WC, Panter KS (2021). Marie Byrd Land I. Volcanology. In: Smellie JL, Panter KS, Geyer A (eds) Volcanism in Antarctica: 200 million years of subduction, rifting and continental break-up. Geol Soc Lond Mem 55: pp. 515-576

Wright IC, Chadwick WW Jr, de Ronde CEJ, Reymond D, Hyvernaud O, Gennerich HH, Stoffers P, Mackay K, Dunkin MA, Bannister SC (2008) Collapse and reconstruction of Monowai submarine volcano, Kermadec arc, 1998-2004. J Geophys Res 113:B08S03. https://doi.org/10.1029/2007JB005138

Zimanowski B, Büttner R (2003) Phreatomagmatic explosions in subaqueous volcanism. In: White JDL, Smellie JL, Clague D (eds) Explosive subaqueous volcanism. American Geophysical Union Geophysical Monograph 140: pp. 51-60 